\title{
Climate-induced land use change in France: impacts of agricultural adaptation and climate change mitigation
}

\author{
Anna Lungarska ${ }^{1}$ \\ Économie Publique, INRA, AgroParisTech, Université Paris-Saclay, 78850 Thiverval-Grignon, France \\ Raja Chakir \\ Économie Publique, INRA, AgroParisTech, Université Paris-Saclay, 78850 Thiverval-Grignon, France.
}

\begin{abstract}
Interaction between mitigation and adaptation is a key question for the design of climate policies. In this paper, we study how land use adaptation to climate change impacts land use competition in the agriculture, forest and other land use (AFOLU) sector and how a mitigation policy in agriculture might affect this competition. We use for this purpose two sector-specific bio-economic models of agriculture and forest combined with an econometric land use shares model to simulate the impacts of two climate change scenarios (A2 and B1, 2100 horizon), and a greenhouse gas emissions from agriculture policy consisting of a tax of between 0 and $200 € / \mathrm{tCO}_{2}$ equivalent. Our results show that both climate change scenarios lead to an increase in the area devoted to agriculture at the expense of forest which could have a negative impact on reducing greenhouse gas emissions responsible for climate change. The mitigation policy would curtail agricultural expansion, and thus could counteract the effects of land use adaptation to climate change. In other words, accounting for land use competition results in a reduction of the abatement costs of the mitigation policy in the agricultural sector.
\end{abstract}

Keywords: Spatial land use share model, greenhouse gas tax, climate change, mitigation, adaptation, land rent, agriculture

JEL Classification: Q15, Q54, Q52, C31

\footnotetext{
Email addresses: Anna.Lungarska@inra.fr (Anna Lungarska), Raja.Chakir@inra.fr (Raja Chakir)

${ }^{1}$ Corresponding author
} 


\section{Introduction}

According to the International Panel on Climate Change (IPCC) (2013), the average global temperature has increased by about $0.85^{\circ} \mathrm{C}$ during the period between 1880 to 2012 . In order to avoid the worst impacts of climate change (CC), requires global greenhouse gas (GHG) emissions to be cut substantially 32. In March 2015, the European Union (EU) announced its intended contribution to the CC mitigation effort by promising a 40\% cut (compared to 1990 levels) in Europe's GHG emissions by 2030. A few months later, during the 2015 United Nations Climate Change Conference (COP 21) held in Paris, France pledged a $75 \%$ emissions reduction by 2050. These ambitious commitments contributed greatly to the adoption of the first universal, legally-binding global climate agreement. The EU's effort is split between member states with each one defining its own mitigation strategy. Thus, the French government announced a national low-carbon strategy [63] which establishes carbon budgets for the 2015-2018, 2019-2023, and 20242028 periods. In order to achieve these national goals, the strategy involves carbon pricing for the energy sector of $22 € / \mathrm{tCO}_{2}$ in $2016,56 € / \mathrm{tCO}_{2}$ in 2020 , and $100 € / \mathrm{tCO}_{2}$ in 2030 .

In France, around $70 \%$ of national GHG emissions come from energy use (in production, transport, residential, etc.) and 16\% - $18 \%{ }^{2}$ from agriculture. In the case of the latter sector, the goal (compared to 2013) is a reduction of some $12 \%$ for the third carbon budget (2024-2028), and a cut of 50\% (compared to 1990) of GHG emissions by 2050 [63. However, no economic incentive policy has been announced for agriculture. [40] discuss the barriers to GHG pricing (cap and trade schemes, taxation) in agriculture, and categorize them into: i) transaction costs; ii) leakages; and iii) distribution effects. Their article proposes a framework for analyzing potential solutions to these issues through policy design. However, the policies currently being considered propose emissions reductions by the agriculture sector through the implementation of agroecological measures such as maintenance of meadows, development of agro-forestry, and optimization of input use.

An exemplary measure which was proposed during COP 22 held in Marrakech in

\footnotetext{
${ }^{2}$ Cited figures are from UNFCC data for France up to 2013. Emissions include LULUCF and indirect $\mathrm{CO}_{2}$.
} 
autumn 2016, is the " 4 per 1000" increase in carbon stock in soils which would reduce atmospheric concentrations. This solution would be associated with gains in terms of soil fertility and supply of other ecosystem services. In this paper, we show how an incentive policy such as GHG taxation in agriculture, could encourage farmers to adopt GHG mitigation means in the direction of the proposed agroecological measures. Such a policy might has an additional indirect effect in the form of land use change (LUC) from agriculture to forestry which could further reduce the costs of GHG emissions abatement.

CC has been ongoing for the last several decades [45], and a policy evaluation in the light of these changes is necessary. For this reason, we investigate the effects of $\mathrm{CC}$ on land use in France at the 2100 horizon, in the context of a CC mitigation policy based on taxing agricultural GHG emissions. We exploit the results from previous work on the impact of CC on the profitability of agriculture and forestry, and estimate a spatial econometric land use share model which captures the changes in land rents for different land use classes. In addition, we study the impact of a mitigation policy (tax on GHG emissions) on land use and on overall agricultural emissions. When accounting for the land use effects of the mitigation policy, we find private abatement costs are lower, and this difference is amplified in different CC scenarios. We build on three branches of the literature on agriculture and $\mathrm{CC}$ adaptation and mitigation: i) impact of $\mathrm{CC}$ on the agricultural sector; ii) impact of CC on land use; and iii) abatement costs related to GHG emissions from agriculture.

First, we draw on the numerous studies assessing the direct effects of $\mathrm{CC}$ on agriculture [2, 71]. According to [61], the literature proposes five approaches to the impacts of CC on agriculture: i) crop simulation models [26]; ii) cross-sectional or intertemporal analyses of yields [53]; iii) panel (intertemporal) analysis of net revenues across weather [31]; iv) crosssectional analyses of net revenues or land values per hectare [60, 59]; and v) computable general equilibrium (CGE) models [64]. Each has limitations and advantages; however, most models do not allow for adaptations to farmer behavior, or possible land use changes outside the agricultural sector. [59] address these issues in part, and propose a method that relies on Ricardian theory of differential land rents. The Ricardian method assumes 
that the land price is the net present value of future land rents. However, future land rents can be driven by factors other than agricultural use [17, 70]. [72] in their assessment of CC impacts on US agriculture, account for urban pressure on agricultural land prices. [1] combine an economic and a crop simulation model to account for some adaptations to crop choice, while [48] go a step further and explore some agronomic adaptations (sowing dates, crop varieties). We build on this body of work and estimate an econometric land use model that allows for LUC among two land based sectors namely agriculture and forestry.

Second, there are some recent studies (6 and 41, for instance) that investigate the effects of $\mathrm{CC}$ on land use. To estimate future land rents for their land use model, [6] use the same principle as [59]. While [59] focus solely on agriculture adaptations related to crops and practices, [6] evaluate the impact of CC in terms of LUCs among annual crops, perennial crops, pastures, forests, and urban areas. [41] investigate LUC by approximating future agricultural and forestry productivity by ecosystem net primary productivity. [37] build on an agricultural land use model [35] to investigate the effect of $\mathrm{CC}$ on water quality. However, their model does not consider other land-demanding economic sectors or their future evolution. In contrast, our methodology allows for LUC not only among sectors but also within the agricultural and forestry sectors (choice of crops and/or pasture, and choice of tree species). This aspect is fundamental when considering CC adaptations.

Third, the marginal abatement costs of GHG for agriculture have been studied using different modeling techniques. In a meta-analysis, [77] classify the different approaches according to three groups: i) supply-side models specialized in agriculture [e.g. 29, 28, 38, ii) general equilibrium models [e.g. 58, 73]; and iii) engineering studies [e.g. 8]. [77] argue that the results of the first model types generally are closer to the microeconomic definition of marginal costs, while general equilibrium models integrate the commodity price responses to pollution abatement. Nevertheless, supply-side models provide a better representation of the heterogeneity in farming systems. The level of detail in descriptions of the production function is even higher in engineering studies but this is at the expense 
of the geographical extent of these studies ${ }^{3}$

With the exception of general equilibrium models, the responses of farmers to GHG taxation in terms of land use is ignored in previous work. Since land use feedback effects have been shown to be important in the context of GHG mitigation policies such as incentives for using biofuels [74, in our simulations we account explicitly for LUC. Finally, [57] estimate an econometric land use model for the USA and simulate landowner responses to sequestration policies. They examine a two-part policy involving a subsidy for converting land to forest, and a tax on converting land from forest. They then estimate the carbon sequestration supply function of these policies by computing the corresponding flows of carbon in terrestrial sinks. However, unlike our study, they do not simulate the impacts of climate change on land use.

The present paper addresses three main questions:

1. What are the impacts of CC on agricultural and forest rents in France?

2. What are the impacts of a mitigation policy (tax on GHG emissions from agriculture) on farms emissions and on LUC in France?

3. What are the impacts of CC on agriculture and LUC in France?

To investigate these questions we exploit the results from two mathematical programming models (AROPAj for agriculture and FFSM++ for forestry) to study the impacts of $\mathrm{CC}$ on agricultural and forest rents. We use the supply model AROPAj to study the impacts of a mitigation policy (tax on GHG) on agriculture, and we use a spatial econometric model to study the impacts of CC and a mitigation policy on LUC. Our econometric model allows for the allocation of land among four land uses, namely: i) agriculture (crops and pasture); ii) forest; iii) urban; and iv) other. We estimate a spatial econometric land use share model which accounts explicitly for spatial autocorrelation between land uses in neighboring grid cells. Most previous work assumes spatial independence of land use choices between neighboring areas, although some recent exceptions include [7, 22, 51, 75, 34, 24. Incorporating spatial autocorrelation into land use models allows for more precise estimation, and improves prediction accuracy [23].

\footnotetext{
${ }^{3}$ For more details on the methodologies and the results of these studies, see [77].
} 
The article is organized as follows. In section 2, we describe the models used to assess GHG emissions from agriculture, and section 3 presents the data. Section 4 presents and discusses the results of our simulations.

\section{Methodology}

The study methodology is based on two mathematical programming models (AROPAj for agriculture, and FFSM++ for forestry), coupled to bio-ecological models, and a spatial econometric land use model that allows us to combine the results of the sector-specific models. Figure 1 describes the modeling scheme adopted. The bio-ecological components of the sector specific models account for the direct impact of $\mathrm{CC}$ on agriculture and forestry in terms of crop and forest yields. These results are integrated in the economic models where economic agents maximize their returns by modifying their input (fertilizer in the case of farmers) and/or land use (crops, tree species). The evaluated rents are used in the econometric land use model to provide estimates of the land shares dedicated to each of the four major land use classes.

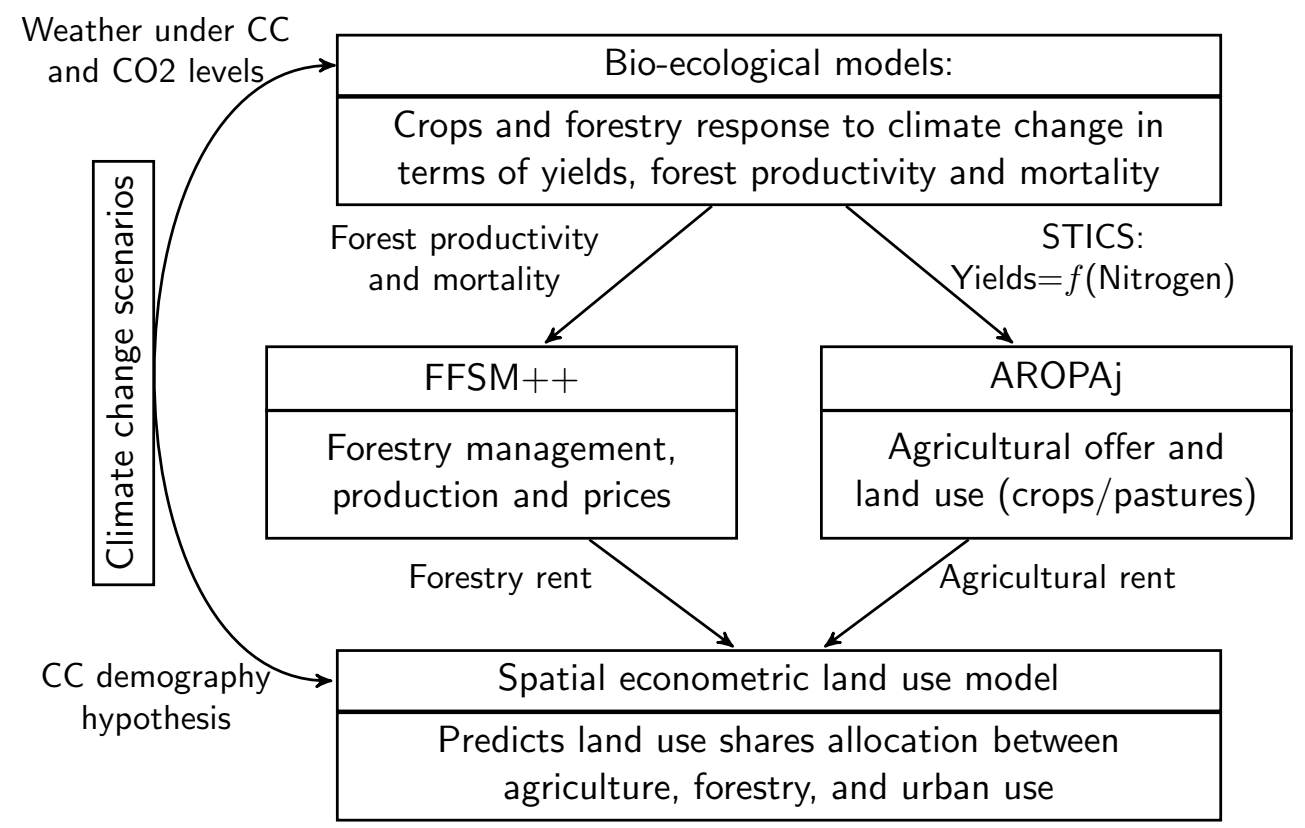

Figure 1: Methodology for the assessment of the climate induced LUC

\subsection{Bio-ecological models}

As depicted in figure 1, CC scenarios (A2 and B1) are simulated first via bio-ecological models. For agriculture, this is the STICS crop model developed by the French National 


\footnotetext{
${ }^{4}$ This work was conducted by Pierre Mérian and Jean-Daniel Bontemps at INRA, Nancy, France.

${ }^{5}$ The type of production (type of farming) and the economic size are defined in the sense of FADN (http://ec.europa.eu/agriculture/rica/diffusion_en.cfm). For instance, farm type 35 in the Rhône-Alpes region is located at low altitude $(<300 \mathrm{~m})$, the economic size of its composing farms is mostly superior to $25,000 €$ /year, and its activities are oriented mainly towards field crops. In the baseline case, its land is used mostly for maize (31\%), wheat $(30 \%)$, sunflower $(14 \%)$ while only a small part of its area is devoted to pastures $(5 \%)$.

${ }^{6}$ Following the duality theorem, the shadow price provides an estimate of the marginal profitability of land, or in other words, its rent (under the economic equilibrium hypothesis).
} 


\footnotetext{
${ }^{7}$ The possibility for conversion is partially limited by some technological constraints imposed during the calibration of the AROPAj model which avoids corner solutions to the model (mono-cropping). Also, the number of animals can vary within a $\pm 15 \%$ interval, otherwise, the model would be out of its calibration interval. However, the choice of animal feed (grazing or fodder) is free.
} 
tion technology (apart from adaptations such as changes to sowing dates, crop varieties, and fertilizer use). Some complementary information related to the CC scenarios' data are provided in subsection 3.3 and in appendix A,

AROPAj models the farmer's choice between land uses in terms of crops and/or pasture. Farmers can choose also among different animal feedstuff: ${ }^{8}$ which has an impact on GHG emissions. We simulate GHG tax levels from 0 to $200 € / \mathrm{tCO}_{2} \mathrm{eq}$; these taxes reduce the profitability of agriculture (ceteris paribus, no price feedback is considered). Therefore, the land shadow price estimated by the model decreases, meaning that agricultural rents are lower. We use these values in the land use share model. AROPAj captures the heterogeneity among farmers in terms of production and response to the tested mitigation policies. This feature of the model is extremely relevant since agriculture is one of the GHG emitting sectors characterized by important heterogeneity among polluters. We also use AROPAj estimates of the shares of pasture and crops chosen by the economic agents.

Forest sector model.. Forestry land rents are approximated by the expected returns estimated by the partial-equilibrium model French Forest Sector Model (FFSM++) [18, 19, 55. The recursive structure of the model is based on two modules - the first is dedicated to the dynamics of wood resources; the second focuses on the sector's market dynamics. Output prices are endogenous for the national market, and exogenous if the international market is considered. Recent developments of the model include spatialization of wood resources [54], and the inclusion of a forestry management module allowing for the introduction of new tree species depending on expected future profits [55]. The expected returns are calculated for 2006 and 2100 at the French administrative region scale (NUTS2). FFSM++ is based on parameters (mortality and tree growth) derived from statistical data. These parameters are estimated using a GAM model [78] under current climate conditions. The results of the FFSM++ simulations in terms of expected

\footnotetext{
${ }^{8}$ For simplicity, we consider that the number of animals is invariant in our simulations. We tested different levels of animal variation $( \pm 15$ and $\pm 30 \%)$ and the results were similar especially for a GHG tax of between $50 € / \mathrm{tCO}_{2}$ eq. and $100 € / \mathrm{tCO}_{2}$ eq.
} 
returns from forestry are summarized in figure 5. Similar to the case of agriculture, the response of forestry returns to $\mathrm{CC}$ is not uniform across regions. Overall, the results for forestry are lower in future climate scenarios.

\subsection{Land use share model}

In line with the literature on LUC, we estimate a land use share model. Land use share models are used widely in the literature [52, 76, 79, 69, 62]. The first step in the modeling procedure assumes that the landowner derives the optimal land allocation from his/her profit-maximization problem. In this paper we focus on the landowner's decision to allocate land among four possible uses: agriculture (crops and pastures), forest, urban, and other. As in [69] and [76] landowners allocate land to the use that provides the highest net present value of future profits. In the second step, and following the literature, we aggregate optimal allocations by individual landowners to derive the observed share of a given land use in each grid cell.

Following [22] and [7], the land use share $S_{g l}$ is computed as the share of the areas in grid $g(\forall g=1, \ldots, G)$ with land use $l(\forall l=1, \ldots, L)$. These shares are written as:

$$
S_{g l}=\frac{\exp \left(\mathbf{R}_{g} \boldsymbol{\beta}_{l}^{R}+\mathbf{P}_{g} \boldsymbol{\beta}_{l}^{P}\right)}{\sum_{l=1}^{L} \exp \left(\mathbf{R}_{g} \boldsymbol{\beta}_{l}^{R}+\mathbf{P}_{g} \boldsymbol{\beta}_{l}^{P}\right)}
$$

where $\mathbf{R}_{g}$ is a vector of land use rents, $\boldsymbol{\beta}_{l}^{R}$ is the associated vector of the parameters to be estimated; $\mathbf{P}_{g}$ is a vector of the physical parameters (soil characteristics and slope) and $\boldsymbol{\beta}_{l}^{S}$ is the vector associated to the parameters to be estimated.

Linearizing the model in equation 1 allows us to estimate equation 2 with a reference land use, $L$

$$
\tilde{S}_{g l}=\ln \left(S_{g l} / S_{g L}\right)=\mathbf{R}_{g} \boldsymbol{\beta}_{l}^{R}+\mathbf{P}_{g} \boldsymbol{\beta}_{l}^{P}+u_{l g}, \forall g=1, \ldots, G, \forall l=1, \ldots, L
$$

In the context of aggregated land use share models, spatial autocorrelation could result from a structural spatial relationship among the values of the dependent variable, or a spatial autocorrelation among the error terms. In the present study, we use an $8 \mathrm{~km} \mathrm{x} 8 \mathrm{~km}$ continuous grid which corresponds to the French climate data grid system, SAFRAN 9

\footnotetext{
${ }^{9}$ More information on this grid is available at https://www.umr-cnrm.fr/spip.php?article788\&
} 
lang=en .

í See [49] which provide motivations for regression models that include spatial autoregressive processes.

Since land use is one of driving forces in local weather conditions, providing land use estimates at this scale should be of use for future research seeking to loop the effects of global CC on land use, and then on local weather conditions. An econometric model that does not include spatial autocorrelation when the data generating process is spatial, could be adversely affected by this omission by bias in the regression coefficients, inconsistency, inefficiency, masking effects of spillovers, prediction bias [4].

Consideration of spatial autocorrelation in an econometric model can be achieved in different ways by including spatially lagged variables, that is, weighted averages of observations of "neighbors" for a given observation [4]. These spatially lagged variables can be the dependent variable (spatial auto-regressive - SAR - model), explanatory variables (spatial cross regressive model, SXM), the dependent and the explanatory variables (spatial Durbin model, SDM), or the error terms (spatial error model, SEM), or any combination of these options which allowing for a range of spatial models [33].

In line with the results in [23], we estimate a spatial Durbin error model (SDEM), which combines SEM and SXM models, using the R package spdep [9, 10]. We use two spatial neighborhood matrices, $W_{1}$ and $W_{2}$. The former represents grid cell neighbors, the latter is built at the administrative region level. Both matrices are based on a Queen contiguity rule. Appendix C|provides some results for the choice of spatial weight matrices. The explanatory variables are lagged with one of these two matrices depending on the geographical scale of the variable. In our model, spatial autocorrelation is essentially a data measurement problem related to explanatory variables such as rent values which are aggregated across space and are likely to be correlated. Spatial autocorrelation can also arise in our case as the result of omitted variables which are spatially correlated ${ }^{10}$.

The SDEM takes account of the interactions between non-observed factors that affect the agricultural land use conversion decision (equation 3). 


$$
\begin{array}{r}
\widetilde{S}_{g l}=\mathbf{R}_{g} \boldsymbol{\beta}_{l}^{R}+\mathbf{P}_{g} \boldsymbol{\beta}_{l}^{P}+W_{1}\left(\mathbf{R}_{g^{\prime}} \beta_{l}^{\mathbf{R}^{\prime}}+\mathbf{P}_{g^{\prime}} \beta_{l}^{\mathbf{P}^{\prime}}\right)+W_{2} \mathbf{R}_{j^{\prime}} \beta_{l}^{\mathbf{R}^{\prime \prime}}+u_{l g} \\
\text { where } u_{l g}=\lambda W_{1} u_{l g}+\varepsilon
\end{array}
$$

$W_{1}$ is an $n \times n$ spatial weight matrix for grid cell neighbors, $W_{2}$ is a $m \times m$ spatial weight matrix for regional neighbors, $\mathbf{R}_{g^{\prime}}$ and $\mathbf{P}_{g^{\prime}}$ are the fine scale explanatory variables for neighboring cells, $\mathbf{R}_{j}$ are regional scale variables for neighboring regions, $\beta_{l}^{\mathbf{R}^{\prime}}, \beta_{l}^{\mathbf{S}^{\prime}}$, and $\beta_{l}^{\mathbf{R}^{\prime \prime}}$ are the associated parameters, the parameter $\lambda$ expresses the interaction between residuals and $\varepsilon$ is an iid ${ }^{11}$ error term such that $\varepsilon \sim i i d\left(0, \sigma^{2} I\right)$.

\section{Data presentation}

General information and descriptive statistics of the variables used in the study are summarized in Table 1 .

\subsection{Land use data}

Land use data are from the Corine Land Cover (CLC) database for France at the scale of $100 \mathrm{~m} \times 100 \mathrm{~m}$ (1ha) grids and for the year 2000. The land cover classes are agriculture, forest, urban, and other. Table 6 in appendix $\mathrm{A}$ summarizes the rules governing the aggregation of land use classes. The resulting map is depicted in figure 2. We next calculate the share of each land use class for each $(8 \mathrm{~km} \times 8 \mathrm{~km})$ grid cell; we know that each cell includes a maximum of 6,400ha. Land use shares are expressed as the sum of the same land use classes in hectares divided by the surface of the grid cell. Although these cells are generated to be homogeneous, they are changed by their intersection with the French borders. For instance, grid cells on the coast are restricted to their parts on dry land.

Since we observe zeros in our land use shares calculated for each $(8 \mathrm{~km} \mathrm{x} 8 \mathrm{~km})$ grid cell, in the cases especially of "other" land use (30\% of grids), urban use (16\% of grids) and to a small extent forest (less than $4 \%$ of grids), this poses two types of problems. First, we cannot calculate the share ratios by dividing on $s_{\text {ot }}$ when it is equal to zero, second,

\footnotetext{
${ }^{11}$ Independent and identically distributed random variable.
} 
we cannot calculate the $\log$ of the ratio of land use shares when $s_{u r}=0$ or $s_{f o}=0$. To deal with these issues, we have chosen to add 0.64ha to each zero land use share for each 6400ha $(8 \mathrm{~km} \times \mathrm{km})$ mesh. We believe this will have no significant impact on our results for the following reason: the minimum CLC mesh size is $6.25 \mathrm{ha}(250 \mathrm{~m} \times 250 \mathrm{~m})$ and CLC assigns land use in relation to the dominant use in each CLC grid. This means that if we have a CLC grid indicated $100 \%$ agriculture then the dominant land use is agriculture but may not be the only land use type present in this grid. Since each of our spatial unit grids (8km x 8km) contains 1,024 CLC meshes, we consider it reasonable to assume that if the observed share is zero at least 0.65 ha are fallow or devoted to "other" land uses (or urban, or forest).

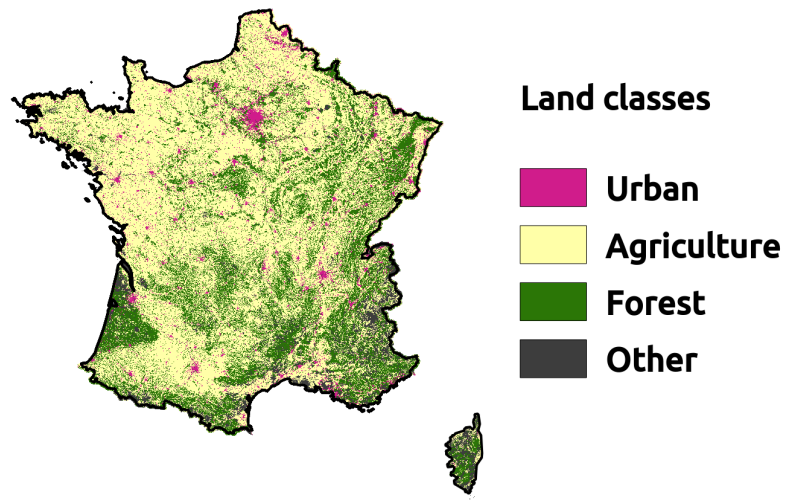

Figure 2: Corine Land Cover (CLC) data aggregated in four land use classes for the year 2000

\subsection{Demography}

For the land use share model estimation, we use an approximation of urban rent based on population density (numbers of households per ha) and household revenues. Both indicators are provided by the French statistical institute (INSEE); revenues are available at the commune scale, and number of households is available for a regular $200 \mathrm{~m} \times 200$ $m$ grid 12

In our CC simulations, we use projections on demographic evolution from INSEE (at the département level up to 2040, and at the national level up to 2060), and estimates from the CIESIN at the Western Europe level [20]. Simple regression models relating

\footnotetext{
${ }^{12}$ INSEE, http://www.insee.fr/fr/themes/detail.asp?reg_id=0\&ref_id=donnees-carroyees\& page=donnees-detaillees/donnees-carroyees/donnees_carroyees_diffusion.htm .
} 
demographic projections from INSEE to those from CIESIN were used to downscale the sub-continental estimates to the French level.

\subsection{Physical data}

In our simulations, we use data on three types of physical parameters: climate, soils, and topography.

Climate.. As already mentioned, we simulate two CC scenarios from the [43, A2 and B1 (see figure 3 for the underlying hypothesis).

The agricultural sector simulations exploit two sets of climate data were used. For calibration purposes (when we seek to adjust our results to a reference year, here 2002) we use reanalyzed ERA-Interim data on a $0.5^{\circ}$ scale (for years 2000, 2001, and 2002 as requested by the crop model). To construct the baseline and the counterfactual climate change scenarios, climate data are from the global climate model (GCM) ECHAM5 and downscaled to the $0.5^{\circ}$. Both grid data are averaged for the FADN region and altitude class combinations $(<300 \mathrm{~m}, 300-600 \mathrm{~m}$, and $>600 \mathrm{~m})$. The crop model requires daily data on several weather parameters such as minimum and maximum temperature, precipitation, radiation, wind, and atmospheric pressure. The modeling steps are in accordance with the climate change simulations methodologies applied by [36] and described in [5]. Another set of data are used for the baseline and counterfactual simulations of the forestry model FFSM ++ which is computed using the ARPEGE model 65] and further downscaled ${ }^{13}$ to an $8 \mathrm{~km} \times 8 \mathrm{~km}$ grid (the same we use in our econometric model) by CERFACS (Centre Européen de Recherche et de Formation Avancée en Calcul Scientifique). Figure 8 provides maps of the evolution of temperatures and precipitations for the two climate scenarios for the ECHAM5 model. Table 5 provides some summary information for the ARPEGE simulations.

Soils. are based on data provided by the Joint Research Centre (JRC, 67) at the scale of 1:1,000,000 and further aggregated to grid cell level. The soil quality indicator we use is

\footnotetext{
${ }^{13}$ For more information on the downscaling procedure see [66, 11, 12]
} 


\begin{tabular}{l|r} 
A1 & A2 \\
- fast economic growth & $\begin{array}{r}\text { - moderate economic growth } \\
\text { - moderate demographic growth } \\
\text { - great technological progress } \\
\text { - increase in temp. } 1.4-6.4{ }^{\circ} \mathrm{C}\end{array}$ \\
\hline - increase in temp. $2.0-5.4{ }^{\circ} \mathrm{C}$ \\
B1
\end{tabular}

Figure 3: Summary of the four major climate change scenarios as presented in [43]

soil texture on four levels. Level 1 , the lowest quality, is the reference. Land quality is an important variable in land use models [22, 3, 56].

Topography. (altitude and slope) is derived from the digital elevation model (DEM) GTOPO, available on a 30 arc seconds scale (approximately $1 \mathrm{~km}$ ). Only slope is introduced in the model because of the high correlation between slope and altitude. Also, slope allows also for better model fit.

This supplementary information is necessary to better integrate the physical heterogeneity in AROPAj estimates of the agricultural land rent. Climate information is less of a determinant in crop simulations than soil data resolution[42]. Therefore, we can conclude that the variability in climate conditions is represented sufficiently well by the aggregated variables at the FADN region scale (the scale of the AROPAj results), with some level of discrimination between altitude levels. However, since soil varies much more, the inclusion of soil quality will enable more precise estimates of land use share model coefficients. This applies especially to the case of slope which is ignored in the STICS simulations supporting the AROPAj model.

\section{Results and simulations}

\subsection{Econometric results of the land use model}

Table 2 presents the estimated coefficients of the econometric land use share models. The estimated Moran's $I$ statistics and the $\lambda$ parameters indicate the presence of significant spatial autocorrelation in all three models. The Akaike information criteria (AIC) 
under the SDEM specification are lower than those for the non-spatial models. The land shadow price has a positive and significant effect on agricultural land use. Forestry revenues have a positive influence on agriculture, forestry, and urban land uses. Urban rent proxies (population density and revenues) have a positive influence on urban $v s$. other uses. Slope and its lagged value have a negative impact on all alternatives to other uses (except forestry for the non-lagged slope) while soil quality has a positive impact. In relation to the lagged values of the land shadow price, the shadow price in neighboring regions has a positive influence on agriculture.

\subsection{Simulations of climate change and GHG taxation}

Impacts of $C C$ on land rents.

. Figures 4 and 5 present the effects of $\mathrm{CC}$ on the agricultural and forestry rent proxies at the NUTS 2 regional level, which is the original geographical scale of the sector specific models AROPAj and FFSM++. As already mentioned, these results capture $\mathrm{CC}$ effects via their respective bio-ecological modules. In general, agriculture revenues (and land shadow price) are higher in the future climate scenario while forestry returns are lower. These results are nuanced by some regional disparities as shown in figures 4 and 5 .

Impacts of $C C$ adaptation and $G H G$ taxes on $L U C$.

. The results of the LUC simulations can be analyzed in terms of: i) the impact of CC on LUC; ii) the impact of GHG taxation on LUC; and iii) their combined impact on LUC. Figure 6 summarizes the results of the simulations.

Impacts of $C C$ adaptation on land use.. Figure 6 shows that our land use model predicts an increase in crop area under the two CC scenarios compared to current climate (CTL scenario). Figure 6 shows also that the increase in the area to crops is more important in B1 scenario, than in the A2 scenario. This increase is at the expenses of forest and pasture. In the case of urban use, the hypothesis underlying the [43] CC scenarios posits an increase in French demography in the A2 scenario, and stabilization or even decrease in the B1 scenario. This hypothesis is demonstrated by the results which show that the 


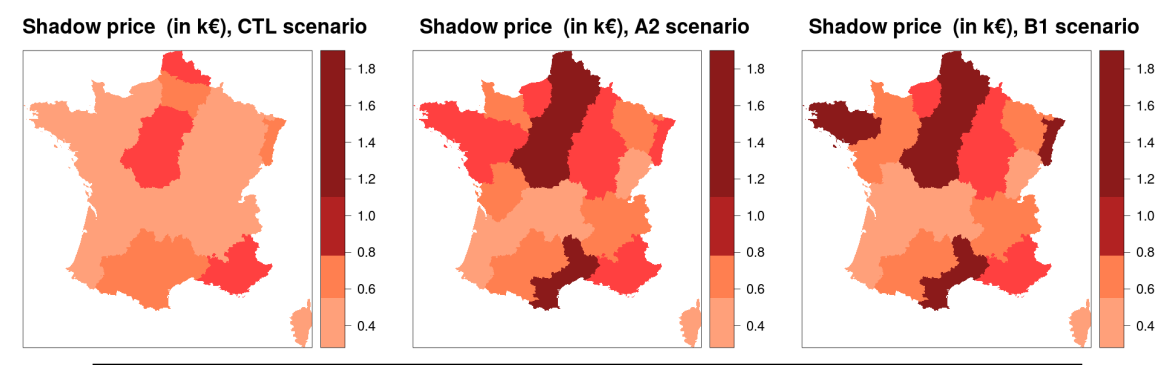

Agricultural land shadow price

\begin{tabular}{lrrrrr} 
& \multicolumn{5}{c}{$\begin{array}{c}\text { Agricultural land shadow price } \\
\text { (quantiles in k€ }\end{array}$} \\
\cline { 2 - 6 } Scenario & $0 \%$ & $25 \%$ & $50 \%$ & $75 \%$ & $100 \%$ \\
\hline Present climate (CTL) & 0.29 & 0.42 & 0.49 & 0.68 & 1.03 \\
A2 & 0.36 & 0.58 & 0.79 & 1.01 & 1.84 \\
B1 & 0.36 & 0.54 & 0.78 & 1.16 & 1.62 \\
\hline
\end{tabular}

Figure 4: Simulated values for the agricultural rent under the current climate (CTL) and for climate change scenarios A2 and B1 (NUTS 2 regional level)

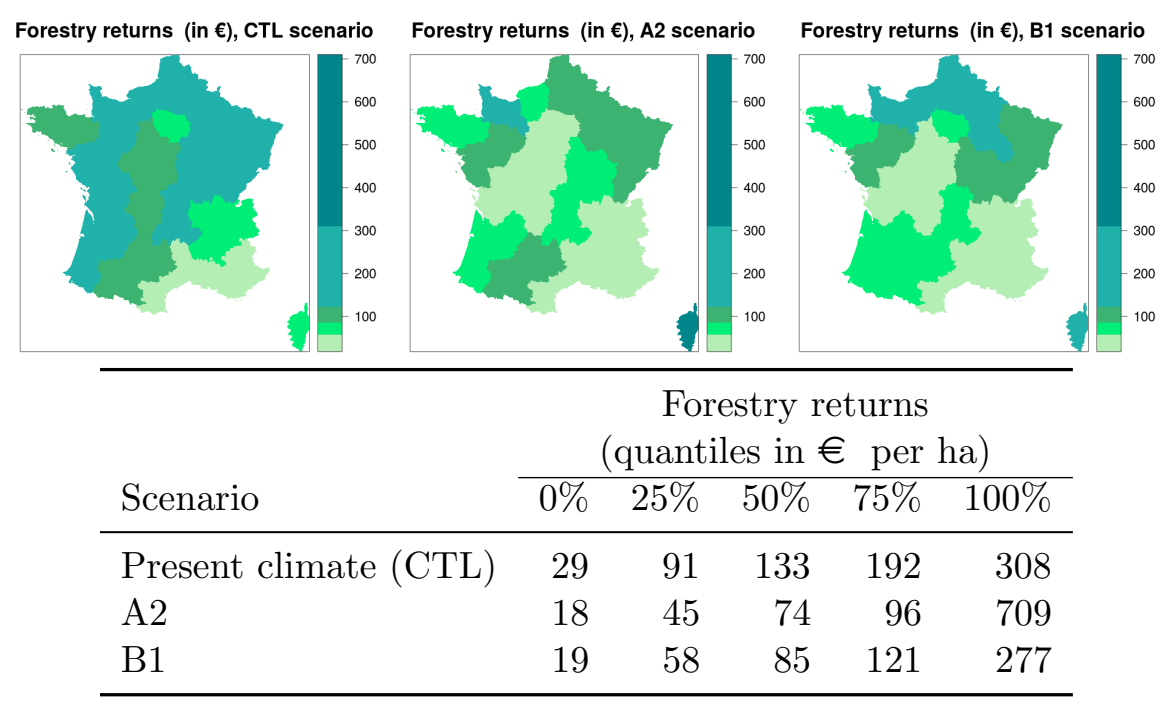

Figure 5: Simulated values for the forestry rent under current climate (CTL) and for climate change scenarios A2 and B1 (NUTS 2 regional level)

urban area increases more in the A2 scenario. We can see also that in the B1 scenario, the greater increase in crop area is associated to a smaller increase in the areas devoted to urban and other uses in this scenario.

Impacts of a GHG mitigation policy on land use.. As expected, taxing the GHG emissions from agriculture reduces the share of agricultural land use due to the lower profitability of that sector. The area to crops is affected more than the area devoted to pasture. As already mentioned, we use the farmers' land allocation decision derived from the AROPAj model, in order to evaluate the share of pastures and crops for each grid cell. The loss 
of agricultural area mainly benefits forest. Our results show that the tax has an effect on both the intensive (lowering the input use per hectare) and the extensive margin of agriculture by reducing the share of agricultural land use. Furthermore, the increase in forest could lead to further GHG mitigation through carbon stocking.

Impacts of the combined $C C$ adaptation and mitigation on land use.. Under both $\mathrm{CC}$ scenarios, taxation of GHG emissions acts to constrain any decrease in forest and pasture areas. Since converting pasture and forest to crops is a source of GHG, the emissions associated with this LUC are avoided by the imposition of the tax. Although the total agricultural area (crop and pasture) in the A2 scenario for a tax of $100 € / \mathrm{tCO}_{2}$ eq. is lower than in the CTL scenario (table 3), the land devoted to crops is increasing.
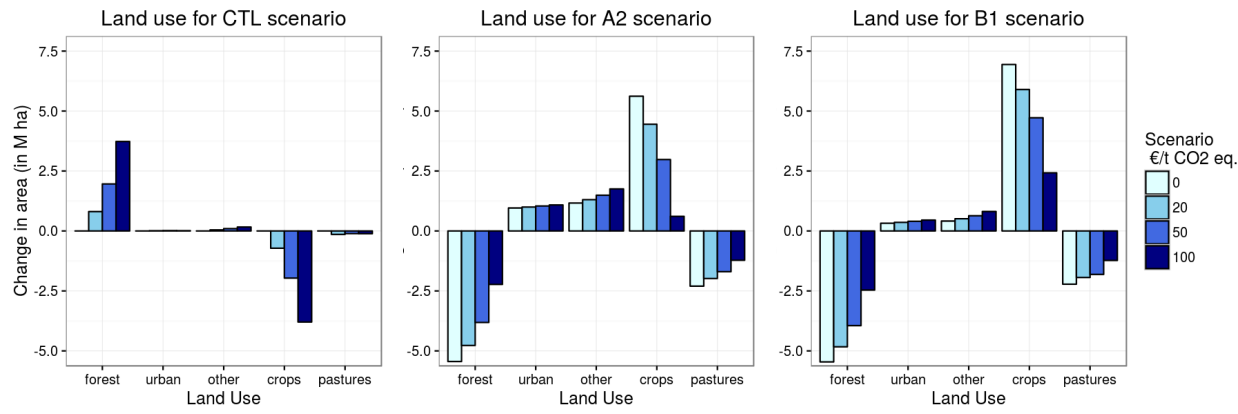

Figure 6: Land use changes depending on climate scenarios and GHG pricing levels

\section{GHG emissions and abatement costs.}

. Figure 7 traces the GHG emissions evolution for the three CC scenarios and the various GHG taxation levels. GHG emissions are increasing under both CC scenarios, because farmers are increasing their nitrogen inputs, and are restricting animal grazing. Figure 7 shows also that if we take account of the potential LUC due to a GHG tax, the reduction in GHG is greater than if we consider the agricultural area as remaining constant. These differences are more important for GHG tax levels higher than $50 € / \mathrm{tCO}_{2}$ eq. Compared to the results in [30] and [77], in our study we find higher abatement rates for the same GHG taxes. For instance, for prices of $20 € / \mathrm{tCO}_{2}$ eq. and $50 € / \mathrm{tCO}_{2}$ eq. we obtain a respective reduction in emissions of about $10 \%$ and $25 \%$ whereas [30] report $6 \%$ and $16 \%$ reductions for France (approximate figures). Also, comparing our results with those from the meta-analysis in [77], we find higher abatement rates. 


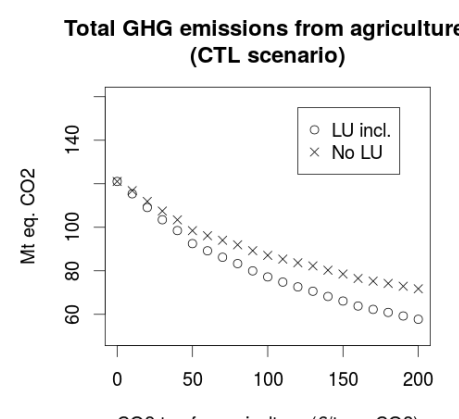

$\mathrm{CO} 2$ tax for agriculture (€/t eq. CO2)

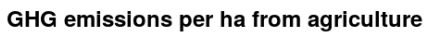
(CTL scenario)

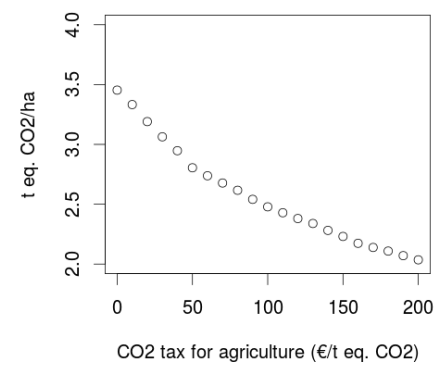

Total GHG emissions from agriculture (A2 scenario)

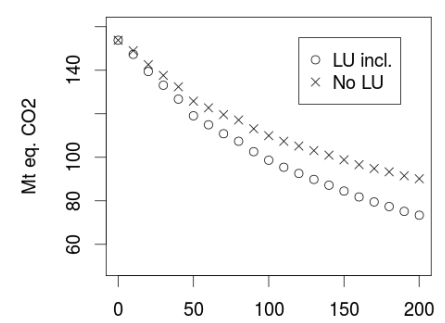

$\mathrm{CO} 2$ tax for agriculture ( $€ / \mathrm{t}$ eq. CO2)

GHG emissions per ha from agriculture (A2 scenario)

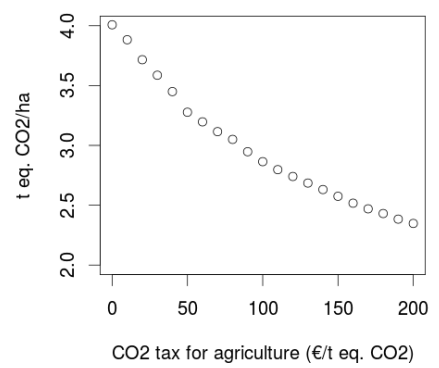

Total GHG emissions from agriculture

(B1 scenario)

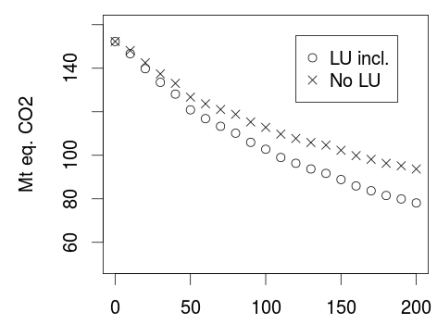

$\mathrm{CO} 2$ tax for agriculture (€/t eq. CO2)

GHG emissions per ha from agriculture (B1 scenario)

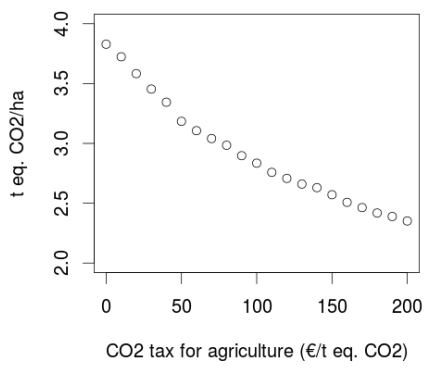

Figure 7: National GHG emissions from agriculture when accounting for LUC

These results are summarized in table 3 which shows the double effect of GHG taxation on the two already-mentioned dimensions: the extensive and the intensive margins of agriculture. The results show that even for high levels of GHG tax, the B1 scenario shows an increase in the agricultural area. Tax levels of $50 € / \mathrm{tCO}_{2}$ eq. allow GHG emissions to stabilize to current levels. Note that these costs are associated not only with a decrease in nitrous oxide and methane emissions but also with a reduction in nitrate and ammonia emissions due to the application of mineral and organic fertilizers [13. In general, economic theory suggests that each pollutant should be targeted individually depending on its environmental impact. Nevertheless, there might be synergies between different environmental objectives.

The targeted $12 \%$ decrease in GHG emissions (French low-carbon strategy, 63) is achieved at $30 € / \mathrm{tCO}_{2}$ eq. when accounting for LUC, and at $40 € / \mathrm{tCO}_{2}$ eq. otherwise. In the A2 scenario, the $12 \%$ cut (compared to the baseline emissions in the CTL scenario) is achieved at $90 € / \mathrm{tCO}_{2}$ eq. (with LUC) and at $120 € / \mathrm{tCO}_{2}$ eq. (with no LUC). In the $\mathrm{B} 1$ scenario, the respective tax levels are $90 € / \mathrm{tCO}_{2}$ eq. and $130 € / \mathrm{tCO}_{2}$ eq. (table 4 . These figures are close to those announced for the energy sector (e.g. $100 € / \mathrm{tCO}_{2}$ in 
2030) and do not account for forest carbon stock which also is affected by GHG taxation. In the context of both the current and the projected future climate, internalization of the negative externalities from agriculture could have a positive effect on the forest area (compared to the no tax scenario). Under current climate conditions, the effect of the taxation would be an overall increase in forest land use compared to the baseline case. $\mathrm{CC}$ has a negative impact on forest land use but this effect is mitigated in part by the simulated public policy. Reforestation or non-deforestation is associated to new carbon sinks or the maintenance of existing ones. This would allow a further reduction in GHG abatement costs. A logical extension to our current work would be integration of the GHG emissions resulting from LUCs. A preliminary assessment of the organic carbon storage variation due to LUCs indicates a relatively low level of $\mathrm{CO}_{2}$ emissions (about $1 \%$ of current agricultural emissions). 


\begin{tabular}{|c|c|c|c|c|c|}
\hline Variable & Description & Mean & St. dev. & Min & $\operatorname{Max}$ \\
\hline \multicolumn{6}{|l|}{ Land use } \\
\hline$s_{a g}$ & Share of crops and pastures & 0.601 & 0.289 & 0 & 1 \\
\hline$s_{f o}$ & Share of forest & 0.264 & 0.225 & 0 & 1 \\
\hline$s_{\text {ur }}$ & Share of urban & 0.049 & 0.093 & 0 & 1 \\
\hline$s_{f o}$ & Share of forest & 0.264 & 0.225 & 0 & 1 \\
\hline$s_{u r}$ & Share of urban & 0.049 & 0.093 & 0 & 0.992 \\
\hline \multirow[t]{3}{*}{$s_{o t}$} & Share of other uses & 0.086 & 0.173 & 0 & 1 \\
\hline & Source: CLC 2000 & & & & \\
\hline & Scale: aggregated at $8 \mathrm{~km} \times 8 \mathrm{~km}$ & & & & \\
\hline \multirow[t]{3}{*}{ Shadow price } & Land shadow price $(\mathrm{k} € /$ ha) & 0.554 & 0.218 & 0 & 1.11 \\
\hline & Source: AROPAj v.2 (2002) & & & & \\
\hline & Scale: NUTS 2 and lower & & & & \\
\hline \multirow[t]{3}{*}{ For revenue } & Forestry revenues $(€ /$ ha $)$ & 137.683 & 66.509 & 28.934 & 308.043 \\
\hline & Source: FFSM++, 2006 & & & & \\
\hline & Scale: NUTS 2 scale & & & & \\
\hline \multirow[t]{4}{*}{ Pop revenues } & Households' revenues $(\mathrm{k} \in /$ year/ & 12.308 & 3.239 & 0 & 41.802 \\
\hline & household) & & & & \\
\hline & Source: INSEE, 2000 & & & & \\
\hline & Scale: French commune & & & & \\
\hline \multirow[t]{4}{*}{ Pop density } & Households density (households/ & 5.432 & 2.274 & 2.75 & 58.722 \\
\hline & ha) & & & & \\
\hline & Source: INSEE, 2000 & & & & \\
\hline & Scale: $200 \mathrm{~m} \times 200 \mathrm{~m}$ grid & & & & \\
\hline \multirow[t]{3}{*}{ Slope } & Slope $(\%)$ & 4.325 & 6.155 & 0 & 47.721 \\
\hline & Source: GTOPO 30 & & & & \\
\hline & Scale: 30 arc sec $\sim 1 \mathrm{~km}$ & & & & \\
\hline \multirow[t]{4}{*}{ Texture } & Soils' texture classes & 1 & 2 & 3 & 4 \\
\hline & Number of cells & 1242 & 4820 & 3120 & 579 \\
\hline & Source: JRC, 67] & & & & \\
\hline & Scale: $1: 1000000$ & & & & \\
\hline
\end{tabular}

Table 1: Summary statistics of land use shares and the explanatory variables 


\begin{tabular}{|c|c|c|c|}
\hline & \multicolumn{3}{|c|}{ Dependent variable: } \\
\hline & $\begin{array}{c}\ln ((\operatorname{agr}+\mathrm{pst}) / \mathrm{oth}) \\
(1)\end{array}$ & $\begin{array}{c}\ln (\text { for } / \text { oth }) \\
(2)\end{array}$ & $\begin{array}{c}\ln (\text { urb/oth }) \\
(3)\end{array}$ \\
\hline Constant & $\begin{array}{c}2.827^{* * *} \\
(0.577)\end{array}$ & $\begin{array}{c}3.104^{* * *} \\
(0.559)\end{array}$ & $\begin{array}{c}-6.269^{* * *} \\
(0.515)\end{array}$ \\
\hline Shadow price (spat) & $\begin{array}{c}0.757^{* *} \\
(0.297)\end{array}$ & $\begin{array}{l}-0.457 \\
(0.296)\end{array}$ & $\begin{array}{c}0.407 \\
(0.297)\end{array}$ \\
\hline For. revenues & $\begin{array}{c}0.003^{* * *} \\
(0.001)\end{array}$ & $\begin{array}{c}0.003^{* * *} \\
(0.001)\end{array}$ & $\begin{array}{c}0.003^{* * *} \\
(0.001)\end{array}$ \\
\hline Pop. density & $\begin{array}{c}-0.131^{* * *} \\
(0.013)\end{array}$ & $\begin{array}{c}-0.145^{* * *} \\
(0.014)\end{array}$ & $\begin{array}{c}0.168^{* * *} \\
(0.015)\end{array}$ \\
\hline Pop. Revenues & $\begin{array}{c}0.047^{* * *} \\
(0.014)\end{array}$ & $\begin{array}{c}0.062^{* * *} \\
(0.014)\end{array}$ & $\begin{array}{c}0.236^{* * *} \\
(0.016)\end{array}$ \\
\hline Slope & $\begin{array}{c}-0.155^{* * *} \\
(0.012)\end{array}$ & $\begin{array}{c}0.027^{* *} \\
(0.013)\end{array}$ & $\begin{array}{c}-0.153^{* * *} \\
(0.014)\end{array}$ \\
\hline Texture (cl.2) & $\begin{array}{c}0.669^{* * *} \\
(0.098)\end{array}$ & $\begin{array}{c}0.315^{* * *} \\
(0.100)\end{array}$ & $\begin{array}{c}0.509^{* * *} \\
(0.111)\end{array}$ \\
\hline Texture (cl.3) & $\begin{array}{c}1.186^{* * *} \\
(0.115)\end{array}$ & $\begin{array}{c}0.675^{* * *} \\
(0.118)\end{array}$ & $\begin{array}{c}0.898^{* * *} \\
(0.129)\end{array}$ \\
\hline Texture (cl.4) & $\begin{array}{c}1.780^{* * *} \\
(0.159)\end{array}$ & $\begin{array}{c}0.982^{* * *} \\
(0.163)\end{array}$ & $\begin{array}{c}0.921^{* * *} \\
(0.180)\end{array}$ \\
\hline Shadow price (W2) & $\begin{array}{l}1.531^{* *} \\
(0.780)\end{array}$ & $\begin{array}{l}-0.594 \\
(0.762)\end{array}$ & $\begin{array}{c}0.932 \\
(0.716)\end{array}$ \\
\hline For. revenues (W2) & $\begin{array}{c}0.011^{* * *} \\
(0.002)\end{array}$ & $\begin{array}{c}0.008^{* * *} \\
(0.002)\end{array}$ & $\begin{array}{c}0.011^{* * *} \\
(0.002)\end{array}$ \\
\hline Pop. density (W1) & $\begin{array}{c}-0.240^{* * *} \\
(0.035)\end{array}$ & $\begin{array}{l}-0.214^{* * *} \\
(0.036)\end{array}$ & $\begin{array}{c}-0.166^{* * *} \\
(0.037)\end{array}$ \\
\hline Pop. Revenues (W1) & $\begin{array}{l}-0.011 \\
(0.029)\end{array}$ & $\begin{array}{l}-0.028 \\
(0.029)\end{array}$ & $\begin{array}{c}0.096^{* * *} \\
(0.029)\end{array}$ \\
\hline Slope (W1) & $\begin{array}{c}-0.140^{* * *} \\
(0.019)\end{array}$ & $\begin{array}{c}-0.118^{* * *} \\
(0.019)\end{array}$ & $\begin{array}{c}-0.099^{* * *} \\
(0.019)\end{array}$ \\
\hline Texture (cl.2, W1) & $\begin{array}{c}0.114 \\
(0.096)\end{array}$ & $\begin{array}{c}0.209^{* *} \\
(0.098)\end{array}$ & $\begin{array}{c}0.344^{* * *} \\
(0.106)\end{array}$ \\
\hline Texture (cl.3, W1) & $\begin{array}{c}0.130 \\
(0.094)\end{array}$ & $\begin{array}{c}0.248^{* * *} \\
(0.095)\end{array}$ & $\begin{array}{c}0.202^{* *} \\
(0.103)\end{array}$ \\
\hline Texture (cl.4, W1) & $\begin{array}{c}0.244^{* *} \\
(0.105)\end{array}$ & $\begin{array}{c}0.083 \\
(0.107)\end{array}$ & $\begin{array}{l}0.193^{*} \\
(0.115)\end{array}$ \\
\hline$N$ & 9761 & & \\
\hline $\mathrm{R} 2$ & 0.634 & 0.443 & 0.558 \\
\hline Moran's I (SLX) & $0.438^{* * *}$ & $0.402^{* * *}$ & $0.343^{* * *}$ \\
\hline Moran's I (residuals) & -0.025 & -0.025 & -0.022 \\
\hline$\lambda$ & $0.759^{* * *}$ & $0.738^{* * *}$ & $0.658^{* * *}$ \\
\hline Log Lik. & -22129.8 & -22391.02 & -23449.93 \\
\hline AIC & 44297.6 & 44820.04 & 46937.86 \\
\hline (AIC for LM) & 48529.63 & 48486.51 & 49561.97 \\
\hline
\end{tabular}

Table 2: Estimated coefficients and their statistical significance for the land use model 


\begin{tabular}{crrrr}
\hline $\begin{array}{c}\text { Climate change } \\
\text { scenario }\end{array}$ & $\begin{array}{r}\text { GHG taxation } \\
\left(€ / \mathrm{tCO}_{2} \text { eq. }\right)\end{array}$ & $\begin{array}{r}\text { All GHG } \\
\text { evolution }(\%)\end{array}$ & $\begin{array}{r}\text { GHG emissions } \\
\text { per ha }\left(\mathrm{tCO}_{2} \text { eq. }\right)\end{array}$ & $\begin{array}{r}\text { Utilized agricultural } \\
\text { area evolution }(\%)\end{array}$ \\
\hline CTL & 0 & 100.00 & 3.453 & 100.00 \\
& 20 & 90.11 & 3.190 & 97.54 \\
& 50 & 76.41 & 2.805 & 94.08 \\
& 100 & 63.76 & 2.478 & 88.85 \\
\hline & & & \\
A2 & 0 & 127.04 & 4.008 & 109.47 \\
& 20 & 115.18 & 3.716 & 107.05 \\
& 50 & 98.36 & 3.277 & 98.65 \\
\hline & 100 & 81.49 & 2.864 & 113.47 \\
B1 & & & 111.29 \\
& 0 & 125.80 & 3.829 & 108.30 \\
& 20 & 115.47 & 3.583 & 103.41 \\
\hline 50 & 99.85 & 3.184 &
\end{tabular}

*Utilized agricultural area equals the sum of land devoted to crops and to pastures.

Table 3: Emission abatement, change in agricultural area, and abatement costs

\begin{tabular}{lrr}
\hline Scenario & With LUC & Without LUC \\
\hline $\mathrm{CTL}$ & $30 € / \mathrm{tCO}_{2} \mathrm{eq}$ & $40 € / \mathrm{tCO}_{2} \mathrm{eq}$ \\
$\mathrm{A} 2$ & $90 € / \mathrm{tCO}_{2} \mathrm{eq}$ & $120 € / \mathrm{tCO}_{2} \mathrm{eq}$ \\
$\mathrm{B} 1$ & $90 € / \mathrm{tCO}_{2} \mathrm{eq}$ & $130 € / \mathrm{tCO}_{2} \mathrm{eq}$ \\
\hline
\end{tabular}

Table 4: Abatement costs (in $€ / \mathrm{tCO}_{2}$ eq.) allowing $12 \%$ decrease in agricultural GHG emissions with or without accounting for LUC 


\section{Conclusion and perspectives}

In the present study, we analyze the impacts of climate change adaptation and a mitigation policy on land use changes in France. We used for this purpose two sectorspecific bio-economic models, AROPAj and FFSM++, and an econometric land use shares model. The effects of climate on agriculture and forestry are captured in a generic crop model and a statistical model of tree growth and mortality. The results obtained were used for an economic modeling of the two sector-specific models. These two models allowed us to evaluate the economic land rents from agriculture and forestry. We estimated a spatial econometric land use model in which agricultural and forestry rents were approximated by the results from the sector-specific models. We studied four land use classes: i) agriculture; ii) forest; iii) urban; and iv) other uses. Our land use shares model accounts for spatial autocorrelation thanks to the spatial Durbin error model specification. We simulated two CC scenarios and GHG taxation levels (from 0 to $200 € / \mathrm{tCO}_{2}$ eq.) aimed at reducing the GHG emissions from agriculture.

The results of our study show that both CC scenarios (A2 and B1) lead to an increase in the agricultural area at the expense of forests. The progression is slower in the A2 compared to the B1 CC scenario. The simulated taxation schemes addressing GHG decrease farmers' profits, and thus curtail some agricultural expansion. This process could reduce the abatement costs associated to public policy. The imposition of GHG taxation under $\mathrm{CC}$ leads to farmers reducing their input use (intensive margin of agriculture) but to a lesser extent converting forest and pasture land to agriculture. This behavior is compatible with the agroecological measures aimed at cutting the sector's GHG emissions. In addition, some potentially "win-win" measures (such as the "4 per 1000" program) could increase abatement rates, and improve soil quality, and thus agricultural productivity.

Our results show that the targeted emissions cut for French agriculture is achievable at a tax level close to the carbon price associated to energy $\mathrm{CO}_{2}$ emissions $\left(100 € / \mathrm{tCO}_{2}\right)$. Furthermore, when the possible agricultural land use feedback of the policy is taken into account, tax levels are lower. A necessary extension of our current work is to assess $\mathrm{CO}_{2}$ emissions and carbon sinks related to the evolution of forests. Taking account of these 
effects of public policy could reduce abatement costs further.

Acknowledgments: We thank Pierre-Alain Jayet for providing us with the results from the AROPAj model, and Antonello Lobianco and Sylvain Caurla for giving us access to the results of the FFSM++ model. We thank the two anonymous referees and the editor of Ecological Economics for their useful comments which have helped us to improve the paper significantly. The usual disclaimers apply. The research leading to these results received funding from the European Union within the European Commission Seventh Framework Programme in the frame of RURAGRI ERA-NET under Grant Agreement 235175 TRUSTEE (ANR-13-RURA-0001-01), and from the French Agence Nationale de la Recherche through the ModULand project (ANR-11-BSH1-005), the ORACLE project (ANR-10-CEPL-011), and STIMUL (Scenarios Towards integrating multi-scale land use tools) flagship project as part of the "Investments d'Avenir" Programme (LabEx BASC; ANR-11-LABX-0034). The authors are solely responsible for any omissions or deficiencies. Neither the French Agence Nationale de la Recherche nor any European Union or European Commission organization is accountable for the content of this research. 
[1] Adams, R. M., Fleming, R. a., Chang, C.-C., McCarl, B. a., Rosenzweig, C., Jun. 1995. A reassessment of the economic effects of global climate change on U.S. agriculture. Climatic Change 30 (2), 147-167.

URL http://link .springer .com/10.1007/BF01091839

[2] Adams, R. M., Rosenzweig, C., Peart, R. M., Ritchie, J. T., McCarl, B. A., Glyer, J. D., Curry, R. B., Jones, J. W., Boote, K. J., Allen, L. H., May 1990. Global climate change and US agriculture. Nature 345 (6272), 219-224.

URL http://www.nature.com/doifinder/10.1038/345219a0

[3] Ahn, S., Plantinga, A. J., Alig, R. J., 2000. Predicting Future Forestland Area : Comparison of Econometric Approaches. Forest Science 46 (2384), 363-376.

[4] Anselin, L., 1988. Spatial Econometrics : Methods and Models. Kluwer Academic Publishers, Dordrecht.

[5] Auffhammer, M., Hsiang, S. M., Schlenker, W., Sobel, A., jul 2013. Using Weather Data and Climate Model Output in Economic Analyses of Climate Change. Review of Environmental Economics and Policy 7 (2), 181-198.

URL https://academic.oup.com/reep/article-lookup/doi/10.1093/reep/ ret016

[6] Ay, J.-S., Chakir, R., Doyen, L., Jiguet, F., Leadley, P., 2014. Integrated models, scenarios and dynamics of climate, land use and common birds. Climatic Change $126(1-2), 13-30$.

[7] Ay, J.-S., Chakir, R., Le Gallo, J., aug 2017. Aggregated Versus Individual Land-Use Models: Modeling Spatial Autocorrelation to Increase Predictive Accuracy. Environmental Modeling \& Assessment advance online publication.

URL http://link. springer.com/10.1007/s10666-016-9523-5

[8] Beach, R. H., DeAngelo, B. J., Rose, S., Li, C., Salas, W., DelGrosso, S. J., mar 2008. Mitigation potential and costs for global agricultural greenhouse gas emissions. Agricultural Economics 38 (2), 109-115.

URL http://doi.wiley.com/10.1111/j.1574-0862.2008.00286.x

[9] Bivand, R., Hauke, J., Kossowski, T., 2013. Computing the jacobian in gaussian spatial autoregressive models: An illustrated comparison of available methods. Geographical Analysis 45 (2), 150-179.

URL http://www . jstatsoft .org/v63/i18/

[10] Bivand, R., Piras, G., 2015. Comparing implementations of estimation methods for spatial econometrics. Journal of Statistical Software 63 (18), 1-36.

URL http: //www . jstatsoft .org/v63/i18/

[11] Boé, J., Terray, L., Habets, F., Martin, E., dec 2006. A simple statistical-dynamical downscaling scheme based on weather types and conditional resampling. Journal of Geophysical Research: Atmospheres 111 (D23).

URL http://doi .wiley.com/10.1029/2005JD006889 
[12] Boé, J., Terray, L., Martin, E., Habets, F., aug 2009. Projected changes in components of the hydrological cycle in French river basins during the 21st century. Water Resources Research 45 (8). URL http://doi .wiley .com/10.1029/2008WR007437

[13] Bourgeois, C., Fradj, N. B., Jayet, P.-A., oct 2014. How Cost-Effective is a Mixed Policy Targeting the Management of Three Agricultural N-pollutants? Environmental Modeling \& Assessment 19 (5), 389-405.

URL http://link.springer.com/10.1007/s10666-014-9401-y

[14] Brisson, N., Gary, C., Justes, E., Roche, R., Mary, B., Ripoche, D., Zimmer, D., Sierra, J., Bertuzzi, P., Burger, P., Bussière, F., Cabidoche, Y., Cellier, P., Debaeke, P., Gaudillère, J., Hénault, C., Maraux, F., Seguin, B., Sinoquet, H., Jan. 2003. An overview of the crop model STICS. European Journal of Agronomy 18 (3-4), 309-332.

URL

http://www.sciencedirect.com/science/article/pii/ S1161030102001107

[15] Brisson, N., Launay, M., Mary, B., Beaudoin, N., 2009. Conceptual Basis, Formalisations and Parameterization of the STICS Crop Model. QUAE.

[16] Cantelaube, P., Jayet, P., Carré, F., Bamps, C., Zakharov, P., 2012. Geographical downscaling of outputs provided by an economic farm model calibrated at the regional level. Land Use Policy 29 (1), 35 - 44.

URL http://www.sciencedirect.com/science/article/pii/ S0264837711000433

[17] Capozza, D. R., Helsley, R. W., Sep. 1990. The stochastic city. Journal of Urban Economics 28 (2), 187-203.

URL http://linkinghub.elsevier.com/retrieve/pii/009411909090050W

[18] Caurla, S., Delacote, P., 2012. Ffsm : un modèle de la filière forêts-bois française qui prend en compte les enjeux forestiers dans la lutte contre le changement climatique. INRA Sciences Sociales 4.

URL http://purl.umn. edu/149688

[19] Caurla, S., Delacote, P., Lecocq, F., Barthès, J., Barkaoui, A., Dec. 2013. Combining an inter-sectoral carbon tax with sectoral mitigation policies: Impacts on the french forest sector. Journal of Forest Economics 19 (4), 450-461.

URL

http://www.sciencedirect.com/science/article/pii/ S1104689913000445

[20] Center for International Earth Science Information Network, 2002. Country-level Population and Downscaled Projections based on the A1, B1, A2 and B2 Scenarios, 1990-2100, [digital version]. http://www.ciesin.columbia.edu/datasets/ downscaled. 
[21] Chakir, R., Jan. 2009. Spatial downscaling of agricultural land-use data: An econometric approach using cross entropy. Land Economics 85 (2), 238-251.

[22] Chakir, R., Le Gallo, J., 2013. Predicting land use allocation in France: A spatial panel data analysis. Ecological Economics 92 (0), 114-125.

[23] Chakir, R., Lungarska, A., 2017. Agricultural rent in land-use models: comparison of frequently used proxies. Spatial Economic Analysis 0 (0), 1-25.

URL http://dx.doi .org/10.1080/17421772.2017.1273542

[24] Chakir, R., Parent, O., 06 2009. Determinants of land use changes: A spatial multinomial probit approach. Papers in Regional Science 88 (2), 327-344.

[25] Chambers, R. G., Just, R. E., nov 1989. Estimating Multioutput Technologies. American Journal of Agricultural Economics 71 (4), 980.

URL https://academic.oup.com/ajae/article-lookup/doi/10.2307/1242674

[26] Ciscar, J.-C., Iglesias, A., Feyen, L., Szabó, L., Van Regemorter, D., Amelung, B., Nicholls, R., Watkiss, P., Christensen, O. B., Dankers, R., Garrote, L., Goodess, C. M., Hunt, A., Moreno, A., Richards, J., Soria, A., 2011. Physical and economic consequences of climate change in europe. Proceedings of the National Academy of Sciences 108 (7), 2678-2683.

[27] Crespo Cuaresma, J., Feldkircher, M., jun 2013. Spatial Filtering, Model Uncertainty and the Speed of Income Convergence in Europe. Journal of Applied Econometrics 28 (4), 720-741.

URL http://doi.wiley.com/10.1002/jae.2277

[28] De Cara, S., Houzé, M., Jayet, P.-A., 2005. Methane and nitrous oxide emissions from agriculture in the EU: a spatial assessment of sources and abatement costs. Environmental and Resource Economics 32 (4), 551-583.

[29] De Cara, S., Jayet, P.-A., sep 2000. Emissions of greenhouse gases from agriculture: the heterogeneity of abatement costs in France. European Review of Agriculture Economics 27 (3), 281-303.

URL http://erae.oupjournals .org/cgi/doi/10.1093/erae/27.3.281

[30] De Cara, S., Jayet, P.-A., 2011. Marginal abatement costs of greenhouse gas emissions from European agriculture, cost effectiveness, and the EU non-ETS burden sharing agreement. Ecological Economics 70 (9), 1680-1690.

[31] Deschenes, O., Greenstone, M., 2007. The economic impacts of climate change: evidence from agricultural output and random fluctuations in weather. The American Economic Review, 354-385.

[32] EEA, 2017. Climate change, impacts and vulnerability in Europe 2016. EEA Report No 1/2017. https://www.eea.europa.eu/ds_resolveuid/KAXZ1FTY4G. 
[33] Elhorst, J. P., 2010. Applied spatial econometrics: Raising the bar. Spatial Economic Analysis 5 (1), 9-28. URL http://www.tandfonline.com/doi/abs/10.1080/17421770903541772

[34] Ferdous, N., Bhat, C. R., jan 2013. A spatial panel ordered-response model with application to the analysis of urban land-use development intensity patterns. Journal of Geographical Systems 15 (1), 1-29.

URL http://link. springer .com/10.1007/s10109-012-0165-0

[35] Fezzi, C., Bateman, I. J., Jul. 2011. Structural agricultural land use modeling for spatial agro-environmental policy analysis. American Journal of Agricultural Economics 93 (4), 1168-1188.

URL http://ajae.oxfordjournals.org/cgi/doi/10.1093/ajae/aar037

[36] Fezzi, C., Bateman, I. J., mar 2015. The Impact of Climate Change on Agriculture: Nonlinear Effects and Aggregation Bias in Ricardian Models of Farmland Values. Journal of the Association of Environmental and Resource Economists 2 (1), 57-92. URL http://www . journals .uchicago.edu/doi/10.1086/680257

[37] Fezzi, C., Harwood, A. R., Lovett, A. A., Bateman, I. J., feb 2015. The environmental impact of climate change adaptation on land use and water quality. Nature Climate Change 5 (3), 255-260.

URL http://dx.doi.org/10.1038/nclimate252510.1038/nclimate2525http: //www.nature.com/nclimate/journal/v5/n3/abs/nclimate2525. html\{\#\}.supplementary-informationhttp://www . nature.com/doifinder/10 . 1038/nclimate2525

[38] Garnache, C., Mérel, P. R., Lee, J., Six, J., mar 2017. The social costs of secondbest policies: Evidence from agricultural GHG mitigation. Journal of Environmental Economics and Management 82, 39-73.

URL http://linkinghub.elsevier .com/retrieve/pii/S0095069616303977

[39] Godard, C., Roger-Estrade, J., Jayet, P., Brisson, N., Le Bas, C., Apr. 2008. Use of available information at a European level to construct crop nitrogen response curves for the regions of the EU. Agricultural Systems 97 (1-2), 68-82.

URL http://linkinghub.elsevier.com/retrieve/pii/S0308521X07001357

[40] Grosjean, G., Fuss, S., Koch, N., Bodirsky, B. L., De Cara, S., Acworth, W., dec 2016. Options to overcome the barriers to pricing European agricultural emissions. Climate Policy, 1-19.

URL https://www.tandfonline.com/doi/full/10.1080/14693062.2016. 1258630

[41] Haim, D., Alig, R. J., Plantinga, A. J., Sohngen, B., Feb. 2011. Climate change and future land use in the united states: an economic approach. Climate Change Economics 02 (01), 27-51. URL http://www . worldscientific.com/doi/abs/10.1142/S2010007811000218 
[42] Hoffmann, H., Zhao, G., Asseng, S., Bindi, M., Biernath, C., Constantin, J., Coucheney, E., Dechow, R., Doro, L., Eckersten, H., Gaiser, T., Grosz, B., Heinlein, F., Kassie, B. T., Kersebaum, K.-C., Klein, C., Kuhnert, M., Lewan, E., Moriondo, M., Nendel, C., Priesack, E., Raynal, H., Roggero, P. P., Rötter, R. P., Siebert, S., Specka, X., Tao, F., Teixeira, E., Trombi, G., Wallach, D., Weihermüller, L., Yeluripati, J., Ewert, F., apr 2016. Impact of Spatial Soil and Climate Input Data Aggregation on Regional Yield Simulations. PLOS ONE 11 (4), e0151782.

URL http://dx.plos.org/10.1371/journal.pone.0151782

[43] IPCC, 2000. Special report on emissions scenarios. Special Report on Emissions Scenarios, Edited by Nebojsa Nakicenovic and Robert Swart, pp. 612. ISBN 0521804930. Cambridge, UK: Cambridge University Press, July 2000. 1.

[44] IPCC, 2013. Summary for Policymakers. In: Climate Change 2013: The Physical Science Basis. Contribution of Working Group I to the Fifth Assessment Report of the Intergovernmental Panel on Climate Change [Stocker, T.F., D. Qin, G.-K. Plattner, M. Tignor, S.K. Allen, J. Boschung, A. Nauels, Y. Xia, V. Bex and P.M. Midgley (eds.)]. Cambridge University Press, Cambridge, United Kingdom and New York, NY, USA.

[45] IPCC, 2014. Climate Change 2014: Impacts, Adaptation, and Vulnerability. Part A: Global and Sectoral Aspects. Contribution of Working Group II to the Fifth Assessment Report of the Intergovernmental Panel on Climate Change.

[46] Jayet, P.-A., Petsakos, A., Chakir, R., Lungarska, A., De Cara, S., Petel, E., Humblot, P., Godard, C., Leclère, D., Cantelaube, P., Bourgeois, C., Bamière, L., Ben Fradj, N., Aghajanzadeh-Darzi, P., Dumollard, G., Ancuta, I., Adrian, J., 2015. The European agro-economic AROPAj model. INRA, UMR Economie Publique, Thiverval-Grignon, https://www6.versailles-grignon. inra.fr/economie_publique_eng/Research-work.

[47] Leclère, D., 2012. Offre agricole Européenne et changement climatique : une exploration régionale des enjeux liés aux changements d'échelle par la modélisation intégrée. Ph.D. thesis, AgroParisTech, dir. P.-A. Jayet.

[48] Leclère, D., Jayet, P.-A., de Noblet-Ducoudré, N., 2013. Farm-level Autonomous Adaptation of European Agricultural Supply to Climate Change. Ecological Economics 87 (0), 1 - 14 .

URL

http://www.sciencedirect.com/science/article/pii/ S092180091200451X

[49] LeSage, J., Pace, R. K., 2009. Introduction to Spatial Econometrics. CRC Press, Boca Raton FL.

[50] LeSage, J. P., Parent, O., jul 2007. Bayesian Model Averaging for Spatial Econometric Models. Geographical Analysis 39 (3), 241-267. URL http://doi.wiley.com/10.1111/j.1538-4632.2007.00703.x 
[51] Li, M., Wu, J., Deng, X., 2013. Identifying drivers of land use change in China: A spatial multinomial logit model analysis. Land Economics 89 (4), 632-654.

[52] Lichtenberg, E., 1989. Land quality, irrigation development, and cropping patterns in the northern high plains. American Journal of Agricultural Economics Vol. 71, No. $1,187-194$.

[53] Lobell, D. B., Schlenker, W., Costa-Roberts, J., 2011. Climate trends and global crop production since 1980. Science 333 (6042), 616-620. URL http://www . sciencemag.org/content/333/6042/616. short

[54] Lobianco, A., Delacote, P., Caurla, S., Barkaoui, A., Aug. 2015. The importance of introducing spatial heterogeneity in bio-economic forest models: Insights gleaned from FFSM++. Ecological Modelling 309-310, 82-92.

URL

http://www.sciencedirect.com/science/article/pii/

\section{S0304380015001635}

[55] Lobianco, A., Delacote, P., Caurla, S., Barkaoui, A., 2016. Accounting for active management and risk attitude in forest sector models. Environmental Modeling \& Assessment 21, 391-405.

URL http://dx.doi .org/10.1007/s10666-015-9483-1

[56] Lubowski, R., Plantinga, A., Stavins, R., 2008. What Drives Land-Use Change in the United States? A National Analysis of Landowner Decisions. Land Econmics 84(4), $551-572$.

[57] Lubowski, R. N., Plantinga, A. J., Stavins, R. N., 2006. Land-use change and carbon sinks: Econometric estimation of the carbon sequestration supply function. Journal of Environmental Economics and Management 51, 135-152.

[58] McCarl, B. A., Schneider, U. A., dec 2001. Climate Change: Greenhouse Gas Mitigation in U.S. Agriculture and Forestry. Science 294 (5551), 2481-2482. URL http://www .sciencemag.org/cgi/doi/10.1126/science.1064193

[59] Mendelsohn, R., Nordhaus, W. D., Shaw, D., 1994. The impact of global warming on agriculture: A Ricardian analysis. American Economic Review 84 (4), 753-771.

[60] Mendelsohn, R., Nordhaus, W. D., SHAw, D., 2004. The impact of global warming on agriculture: A ricardian analysis. Climate change, 99-117.

[61] Mendelsohn, R. O., Dinar, A., 2009. Climate change and agriculture: an economic analysis of global impacts, adaptation and distributional effects. Edward Elgar Publishing.

[62] Miller, D. J., Plantinga, A. J., 1999. Modeling land use decisions with aggregate data. American Journal of Agricultural Economics 81(1), 180-194. 
[63] Ministère de l'écologie, du développement durable et de l'énergie, 2015. Stratégie nationale bas-carbone.

URL http://www.developpement-durable.gouv.fr/ Strategie-nationale-bas-carbone.html

[64] Nelson, G. C., Valin, H., Sands, R. D., Havlík, P., Ahammad, H., Deryng, D., Elliott, J., Fujimori, S., Hasegawa, T., Heyhoe, E., Kyle, P., Von Lampe, M., Lotze-Campen, H., Mason d'Croz, D., van Meijl, H., van der Mensbrugghe, D., Müller, C., Popp, A., Robertson, R., Robinson, S., Schmid, E., Schmitz, C., Tabeau, A., Willenbockel, D., 2014. Climate change effects on agriculture: Economic responses to biophysical shocks. Proceedings of the National Academy of Sciences 111 (9), 3274-3279. URL http://www . pnas . org/content/111/9/3274 . abstract

[65] Pagé, C., Terray, L., 2010. Nouvelles projections climatiques à échelle fine sur la France pour le 21ème siècle : les scénarii SCRATCH2010. Technical Report TR/CMGC/10/58, SUC au CERFACS, URA CERFACS/CNRS No1875CS, Toulouse, France.

[66] Pagé, C., Terray, L., Boé, J., 2010. Cdsclim: A software package to downscale climate scenarios at regional scale using a weather-typing based statistical methodology. Technical Report TR/CMGC/09/21, SUC au CERFACS, URA CERFACS/CNRS No1875, Toulouse, France.

[67] Panagos, P., Van Liedekerke, M., Jones, A., Montanarella, L., Apr. 2012. European Soil Data Centre: Response to European policy support and public data requirements. Land Use Policy 29 (2), 329-338. URL http://linkinghub.elsevier.com/retrieve/pii/S0264837711000718

[68] Piribauer, P., Fischer, M. M., jul 2015. Model Uncertainty in Matrix Exponential Spatial Growth Regression Models. Geographical Analysis 47 (3), 240-261. URL http://doi .wiley .com/10.1111/gean.12057

[69] Plantinga, A. J., 1996. The effect of agricultural policies on land use and environmental quality. American Journal of Agricultural Economics 78 (4), 1082-1091.

[70] Plantinga, A. J., Lubowski, R. N., Stavins, R. N., 2002. The effects of potential land development on agricultural land prices. Journal of Urban Economics 52 (3), $561-581$.

URL http://www.sciencedirect.com/science/article/pii/ S009411900200503X

[71] Rosenzweig, C., Parry, M. L., Jan. 1994. Potential impact of climate change on world food supply. Nature 367 (6459), 133-138.

URL http://www . nature.com/doifinder/10.1038/367133a0

[72] Schlenker, W., Hanemann, W. M., Fisher, A. C., 2005. Will us agriculture really benefit from global warming? accounting for irrigation in the hedonic approach. American Economic Review, 395-406. 
[73] Schneider, U. A., McCarl, B. A., nov 2006. Appraising agricultural greenhouse gas mitigation potentials: effects of alternative assumptions. Agricultural Economics 35 (3), 277-287.

URL http://doi.wiley.com/10.1111/j.1574-0862.2006.00162.x

[74] Searchinger, T., Heimlich, R., Houghton, R. A., Dong, F., Elobeid, A., Fabiosa, J., Tokgoz, S., Hayes, D., Yu, T.-H., feb 2008. Use of U.S. Croplands for Biofuels Increases Greenhouse Gases Through Emissions from Land-Use Change. Science 319 (5867), 1238-1240.

URL http://www.sciencemag.org/cgi/doi/10.1126/science.1151861

[75] Sidharthan, R., Bhat, C. R., 2012. Incorporating spatial dynamics and temporal dependency in land use change models. Geographical Analysis 44 (4), 321-349. URL http://dx.doi .org/10.1111/j.1538-4632.2012.00854.x

[76] Stavins, R. N., Jaffe, A. B., 1990. Unintended impacts of public investments on private decisions: The depletion of forested wetlands. American Economic Review 80(3), 337-352.

[77] Vermont, B., De Cara, S., May 2010. How costly is mitigation of non-CO2 greenhouse gas emissions from agriculture?: A meta-analysis. Ecological Economics 69 (7), 13731386.

URL http://ideas.repec.org/a/eee/ecolec/v69y2010i7p1373-1386.html

[78] Wood, S., 2006. Generalized Additive Models: An Introduction with R. Chapman \& Hall/CRC Texts in Statistical Science. Taylor \& Francis.

[79] Wu, J., Segerson, K., 1995. The Impact of Policies and Land Characteristics on Potential Groundwater Pollution in Wisconsin. American Journal of Agricultural Economics 77 (4), 1033-1047. 


\begin{tabular}{llrrrrrr}
\hline \multirow{2}{*}{ Variable } & \multicolumn{3}{c}{ Dec-Jan-Feb } & \multicolumn{2}{c}{ Jun-Jul-Aug } & \multicolumn{2}{c}{ Period } \\
& Units & Mean & STDDEV & Mean & STDDEV & Mean & STDDEV \\
\hline B1 precipitation & $\mathrm{mm} / \mathrm{y}$ & -164 & 330 & -94 & 181 & -138 & 126 \\
B1 temperature & ${ }^{\circ} \mathrm{C}$ & 1.60 & 1.46 & 1.11 & 0.59 & 1.57 & 0.48 \\
A2 precipitation & $\mathrm{mm} / \mathrm{y}$ & -175 & 328 & -112 & 202 & -209 & 113 \\
A2 temperature & ${ }^{\circ} \mathrm{C}$ & 3.18 & 1.26 & 3.52 & 0.78 & 3.44 & 0.51 \\
\hline
\end{tabular}

Table 5: Mean and standard deviation for the anomalies in precipitations and temperature for 2081-2100 vs 1961-1990 (ARPEGE model) 


\section{Changes in mean seasonal temperature}
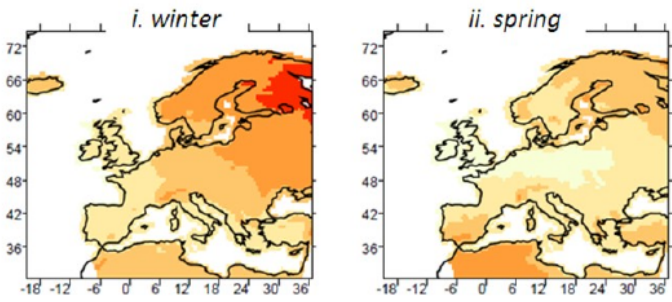

$\begin{array}{llllllllll}-2 & -1 & 0 & 1 & 2 & 3 & 4 & 6 & 8 & {\left[{ }^{\circ} \mathrm{C}\right]}\end{array}$

iii. summer

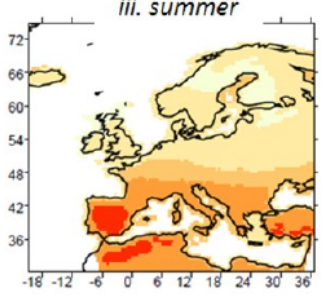

(a) A2 scenario
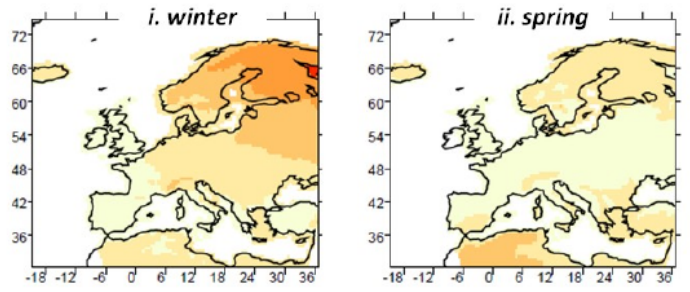

$\begin{array}{llllllllll}-2 & -1 & 0 & 1 & 2 & 3 & 4 & 6 & 8 & {\left[{ }^{\circ} \mathrm{C}\right]}\end{array}$
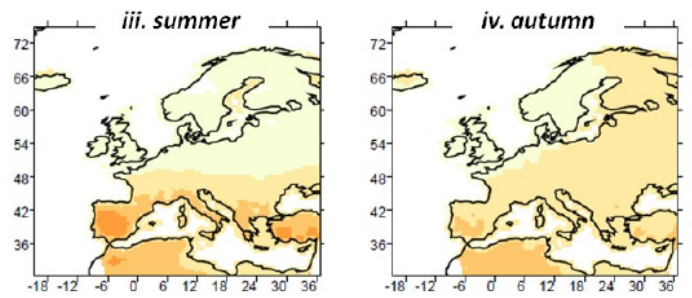

(b) B1 scenario

\section{Changes in seasonal precipitation cumul}
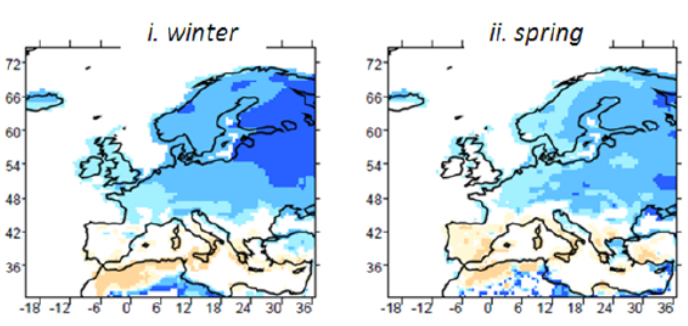

$\begin{array}{llllllllll}-100 & -75 & -50 & -25 & -10 & 0 & 10 & 25 & 50 & 100[\%]\end{array}$

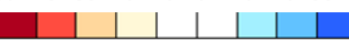
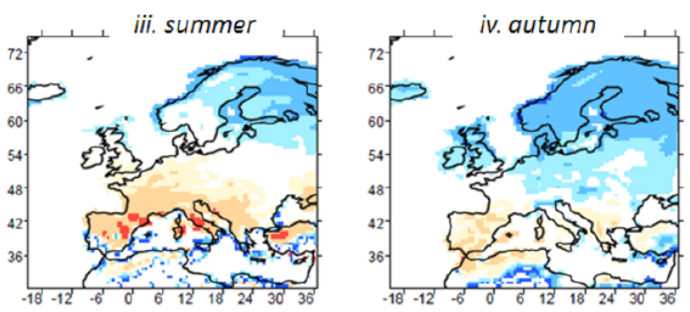

(a) A2 scenario
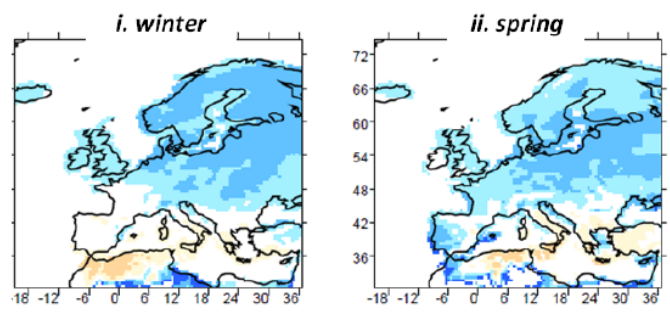

$\begin{array}{llllllllll}-100 & -75 & -50 & -25 & -10 & 0 & 10 & 25 & 50 & 100[\%]\end{array}$
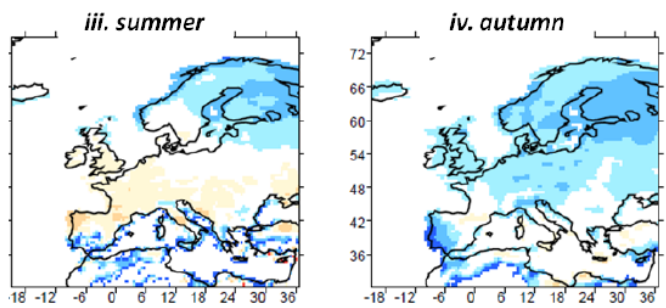

(b) B1 scenario

Figure 8: Climate change projections for the A2 and B1 scenarios (ECHAM5 model), source 47. 


\begin{tabular}{lrr}
\hline Land Cover class & CLC value & LU class \\
\hline 1 Artificial Surfaces & $1, \ldots, 11$ & Urban \\
2 Agricultural Areas & $12, \ldots, 22$ & Agriculture \\
3.1 Forests & $23, \ldots, 25$ & Forest \\
3.2 Shrub and/or herbaceous vegetation associations & $26, \ldots, 29$ & Other \\
3.3 Open spaces with little or no vegetation & $30, \ldots, 34$ & Other \\
4 Wetlands & $35, \ldots, 39$ & Other \\
5 Water bodies & $40, \ldots, 44$ & Other \\
\hline
\end{tabular}

Table 6: Extract from the CLC classification and the corresponding LU aggregation 


\section{Appendix B Predicted land use shares}

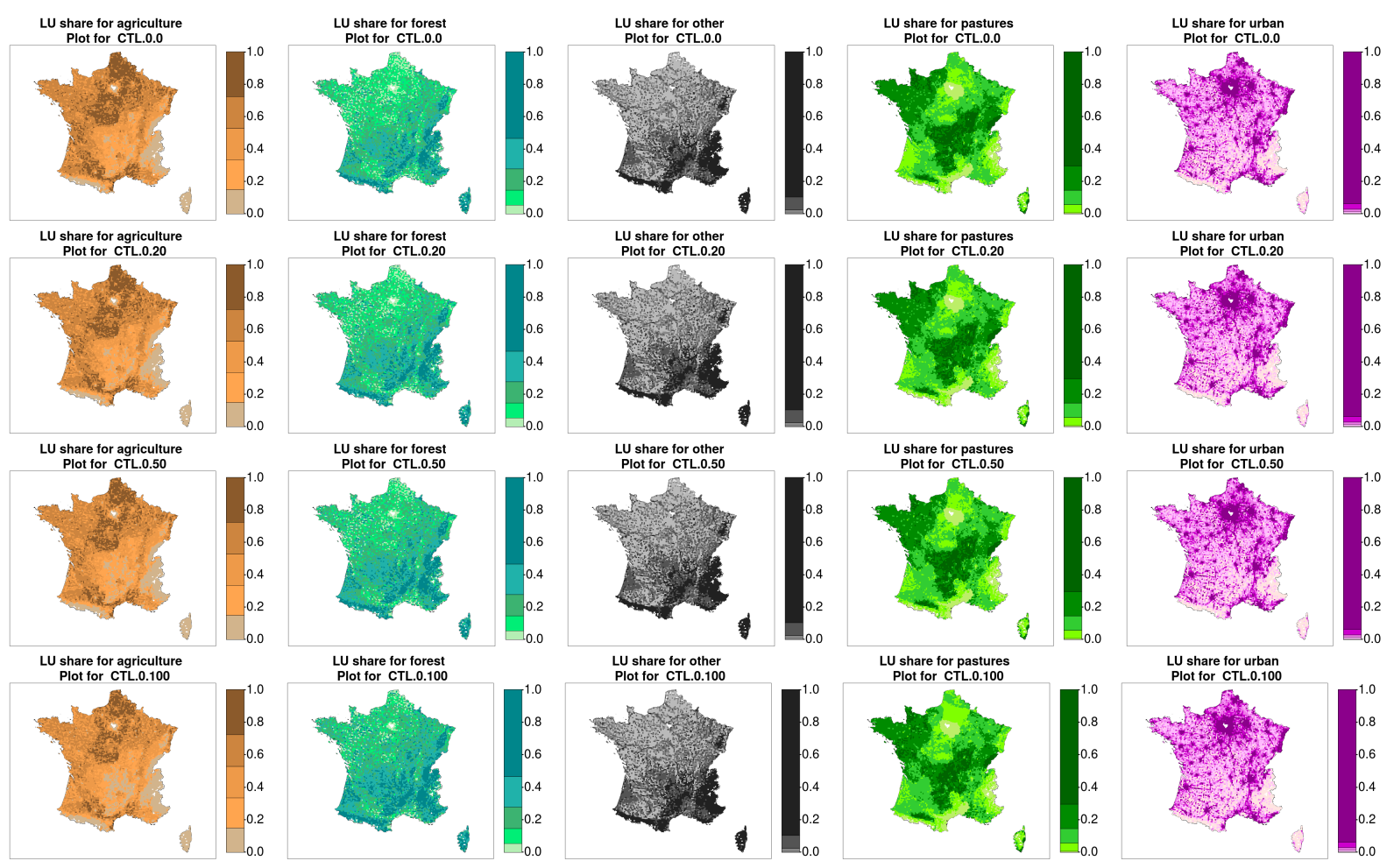

Figure 9: Land use depending on the tax level and climate scenario CTL 


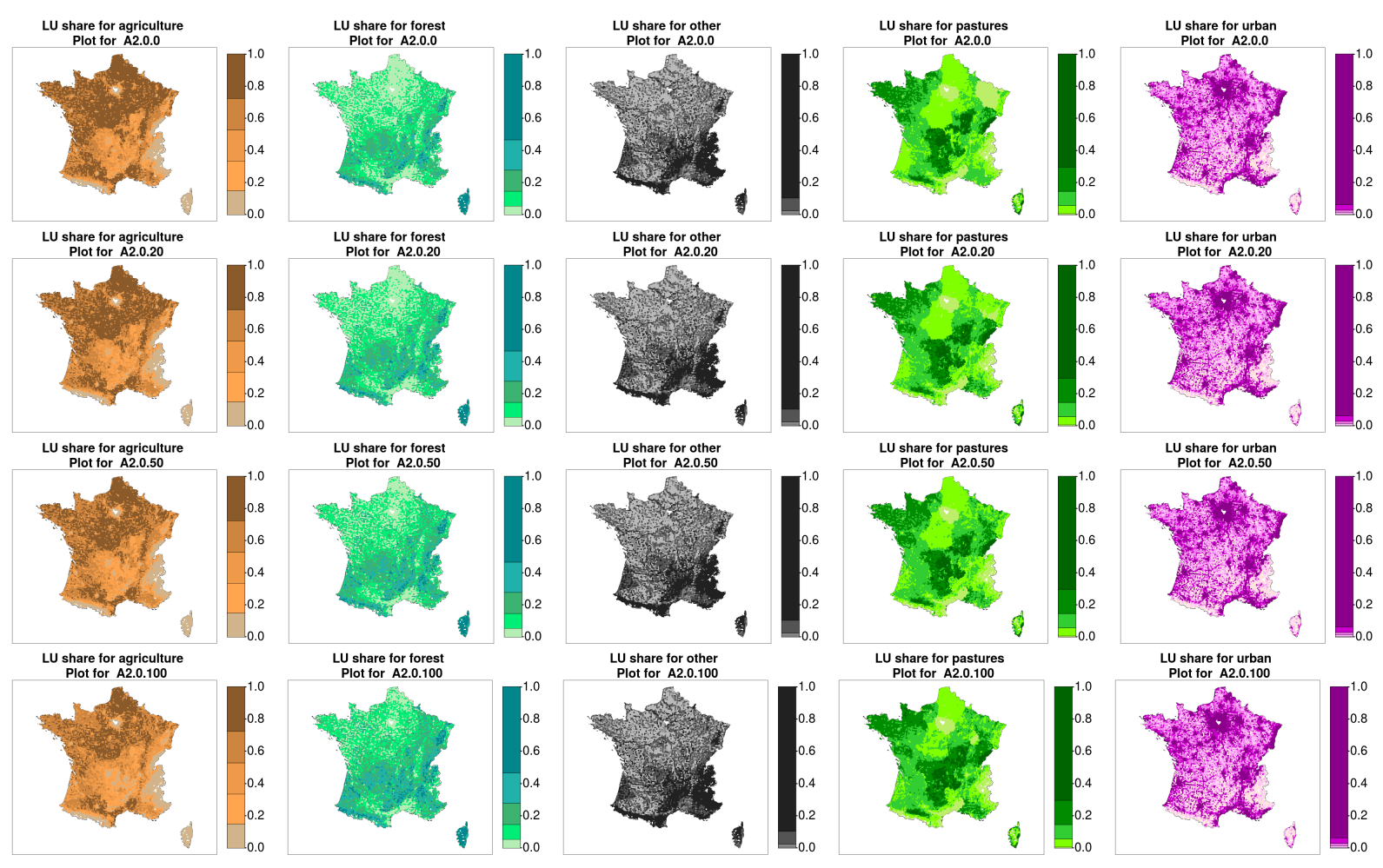

Figure 10: Land use depending on the tax level and climate change scenario A2

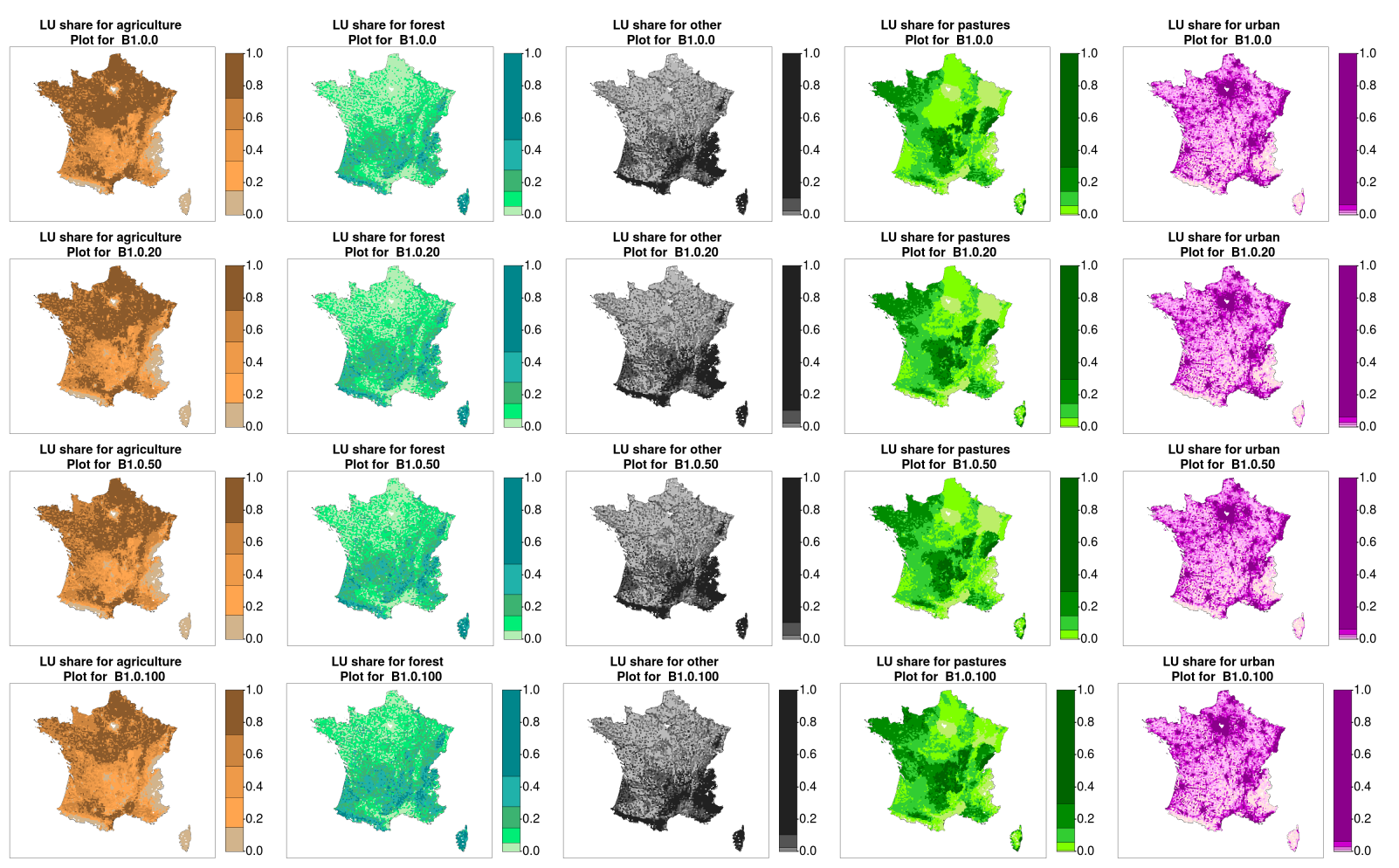

Figure 11: Land use depending on the tax level and climate change scenario B1 


\section{Appendix C Comparison of neighborhood matrices}

Following the discussion on neighborhood weight matrices in the spatial econometrics literature [e.g. 27, 50, 68], we tested three neighborhood matrices for the grid cells $\left(1^{\text {st }}\right.$, $2^{\text {nd }}$, and $3^{\text {rd }}$ order neighbors) and two neighborhood matrices for the regions $\left(1^{\text {st }}\right.$ and $2^{\text {nd }}$ order neighbors). The results of these five neighborhood matrices combinations show that we can stick to the $1^{\text {st }}$ order grid and regional matrices. In terms of explanatory power, only one of the alternative matrices specifications leads to better results (higher $R^{2}$ and $\log$ likelihood, lower Akaike information criterion). However, since our main interest is in estimating an econometric model to allow predictions, we consider the estimated coefficients to be more intuitive under the $1^{\text {st }}$ order neighborhood matrices. 


\begin{tabular}{|c|c|c|c|}
\hline & \multicolumn{3}{|c|}{ Dependent variable: } \\
\hline & $\begin{array}{c}\ln ((\text { agr }+ \text { pst }) / \text { oth }) \\
(1)\end{array}$ & $\begin{array}{c}\ln (\text { for } / \text { oth }) \\
(2)\end{array}$ & $\begin{array}{c}\ln (\text { urb/oth }) \\
(3)\end{array}$ \\
\hline Constant & $\begin{array}{c}2.827^{* * *} \\
(0.577)\end{array}$ & $\begin{array}{c}3.104^{* * *} \\
(0.559)\end{array}$ & $\begin{array}{c}-6.269^{* * *} \\
(0.515)\end{array}$ \\
\hline Shadow price (spat) & $\begin{array}{c}0.757^{* *} \\
(0.297)\end{array}$ & $\begin{array}{l}-0.457 \\
(0.296)\end{array}$ & $\begin{array}{c}0.407 \\
(0.297)\end{array}$ \\
\hline For. revenues & $\begin{array}{c}0.003^{* * *} \\
(0.001)\end{array}$ & $\begin{array}{c}0.003^{* * *} \\
(0.001)\end{array}$ & $\begin{array}{c}0.003^{* * *} \\
(0.001)\end{array}$ \\
\hline Pop. density & $\begin{array}{c}-0.131^{* * *} \\
(0.013)\end{array}$ & $\begin{array}{c}-0.145^{* * *} \\
(0.014)\end{array}$ & $\begin{array}{c}0.168^{* * *} \\
(0.015)\end{array}$ \\
\hline Pop. Revenues & $\begin{array}{c}0.047^{* * *} \\
(0.014)\end{array}$ & $\begin{array}{c}0.062^{* * *} \\
(0.014)\end{array}$ & $\begin{array}{c}0.236^{* * *} \\
(0.016)\end{array}$ \\
\hline Slope & $\begin{array}{c}-0.155^{* * *} \\
(0.012)\end{array}$ & $\begin{array}{l}0.027^{* *} \\
(0.013)\end{array}$ & $\begin{array}{c}-0.153^{* * *} \\
(0.014)\end{array}$ \\
\hline Texture (cl.2) & $\begin{array}{c}0.669^{* * *} \\
(0.098)\end{array}$ & $\begin{array}{c}0.315^{* * *} \\
(0.100)\end{array}$ & $\begin{array}{c}0.509^{* * *} \\
(0.111)\end{array}$ \\
\hline Texture (cl.3) & $\begin{array}{c}1.186^{* * *} \\
(0.115)\end{array}$ & $\begin{array}{c}0.675^{* * *} \\
(0.118)\end{array}$ & $\begin{array}{c}0.898^{* * *} \\
(0.129)\end{array}$ \\
\hline Texture (cl.4) & $\begin{array}{c}1.780^{* * *} \\
(0.159)\end{array}$ & $\begin{array}{c}0.982^{* * *} \\
(0.163)\end{array}$ & $\begin{array}{c}0.921^{* * *} \\
(0.180)\end{array}$ \\
\hline Shadow price (W2) & $\begin{array}{l}1.531^{* *} \\
(0.780)\end{array}$ & $\begin{array}{l}-0.594 \\
(0.762)\end{array}$ & $\begin{array}{c}0.932 \\
(0.716)\end{array}$ \\
\hline For. revenues (W2) & $\begin{array}{l}0.011^{* * *} \\
(0.002)\end{array}$ & $\begin{array}{c}0.008^{* * *} \\
(0.002)\end{array}$ & $\begin{array}{c}0.011^{* * *} \\
(0.002)\end{array}$ \\
\hline Pop. density (W1) & $\begin{array}{c}-0.240^{* * *} \\
(0.035)\end{array}$ & $\begin{array}{c}-0.214^{* * *} \\
(0.036)\end{array}$ & $\begin{array}{c}-0.166^{* * *} \\
(0.037)\end{array}$ \\
\hline Pop. Revenues (W1) & $\begin{array}{l}-0.011 \\
(0.029)\end{array}$ & $\begin{array}{l}-0.028 \\
(0.029)\end{array}$ & $\begin{array}{c}0.096^{* * *} \\
(0.029)\end{array}$ \\
\hline Slope (W1) & $\begin{array}{c}-0.140^{* * *} \\
(0.019)\end{array}$ & $\begin{array}{c}-0.118^{* * *} \\
(0.019)\end{array}$ & $\begin{array}{c}-0.099^{* * *} \\
(0.019)\end{array}$ \\
\hline Texture (cl.2, W1) & $\begin{array}{c}0.114 \\
(0.096)\end{array}$ & $\begin{array}{l}0.209 * * \\
(0.098)\end{array}$ & $\begin{array}{c}0.344^{* * *} \\
(0.106)\end{array}$ \\
\hline Texture (cl.3, W1) & $\begin{array}{c}0.130 \\
(0.094)\end{array}$ & $\begin{array}{c}0.248^{* * *} \\
(0.095)\end{array}$ & $\begin{array}{l}0.202^{* *} \\
(0.103)\end{array}$ \\
\hline Texture (cl.4, W1) & $\begin{array}{c}0.244^{* *} \\
(0.105)\end{array}$ & $\begin{array}{c}0.083 \\
(0.107)\end{array}$ & $\begin{array}{l}0.193^{*} \\
(0.115)\end{array}$ \\
\hline$N$ & 9761 & & \\
\hline $\mathrm{R} 2$ & 0.634 & 0.443 & 0.558 \\
\hline Moran's I (SLX) & $0.438^{* * *}$ & $0.402^{* * *}$ & $0.343^{* * *}$ \\
\hline Moran's I (residuals) & -0.025 & -0.025 & -0.022 \\
\hline$\lambda$ & $0.759^{* * *}$ & $0.738^{* * *}$ & $0.658^{* * *}$ \\
\hline Log Lik. & -22129.8 & -22391.02 & -23449.93 \\
\hline AIC & 44297.6 & 44820.04 & 46937.86 \\
\hline (AIC for LM) & 48529.63 & 48486.51 & 49561.97 \\
\hline
\end{tabular}

Note:

${ }^{*} \mathrm{p}<0.1 ;{ }^{* *} \mathrm{p}<0.05 ;{ }^{* * *} \mathrm{p}<0.01$

Table 7: Spatialized dual value, $4 \mathrm{LU}, 1^{\text {st }}$ order $W_{1}$ and $W_{2}$ 


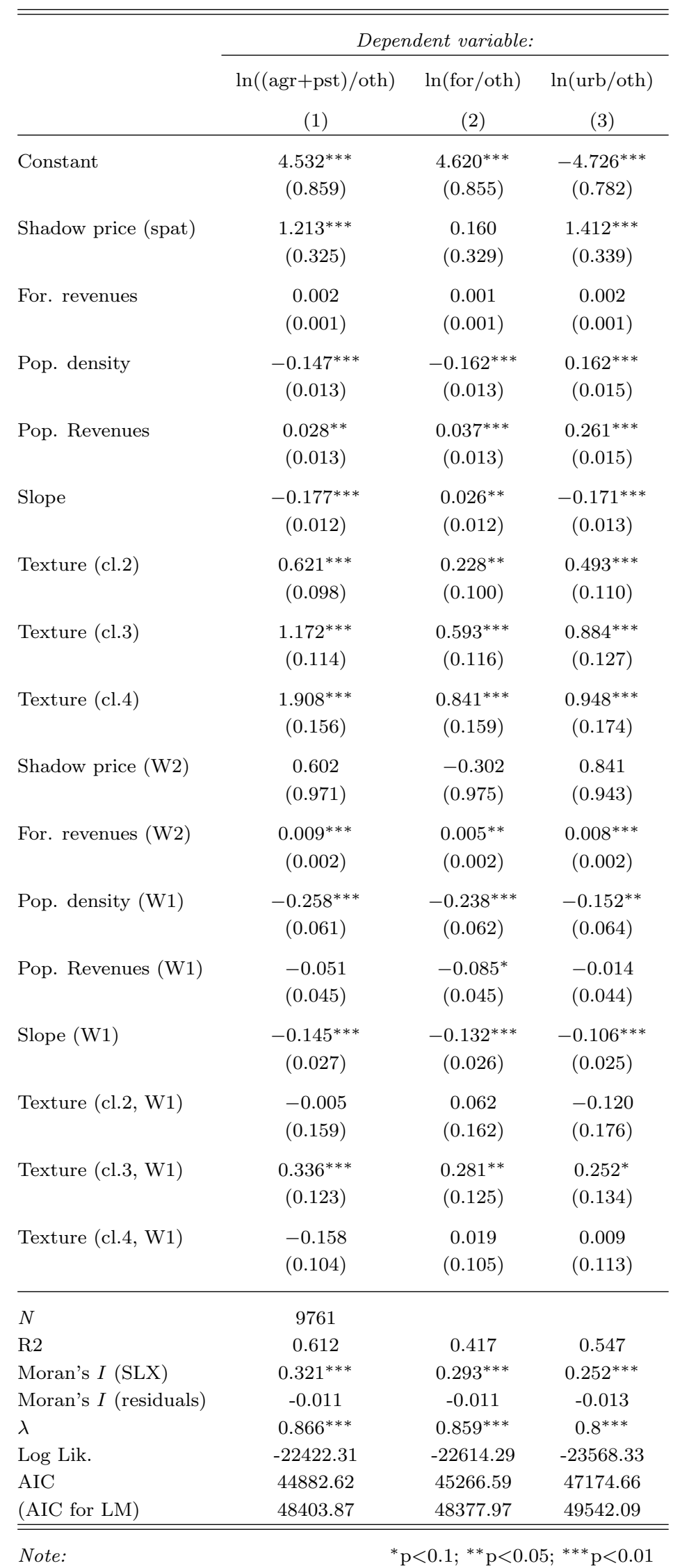

Table 8: Spatialized dual value, $4 \mathrm{LU}, 2^{\text {nd }}$ order $W_{1}, 1^{\text {st }}$ order $W_{2}$ 


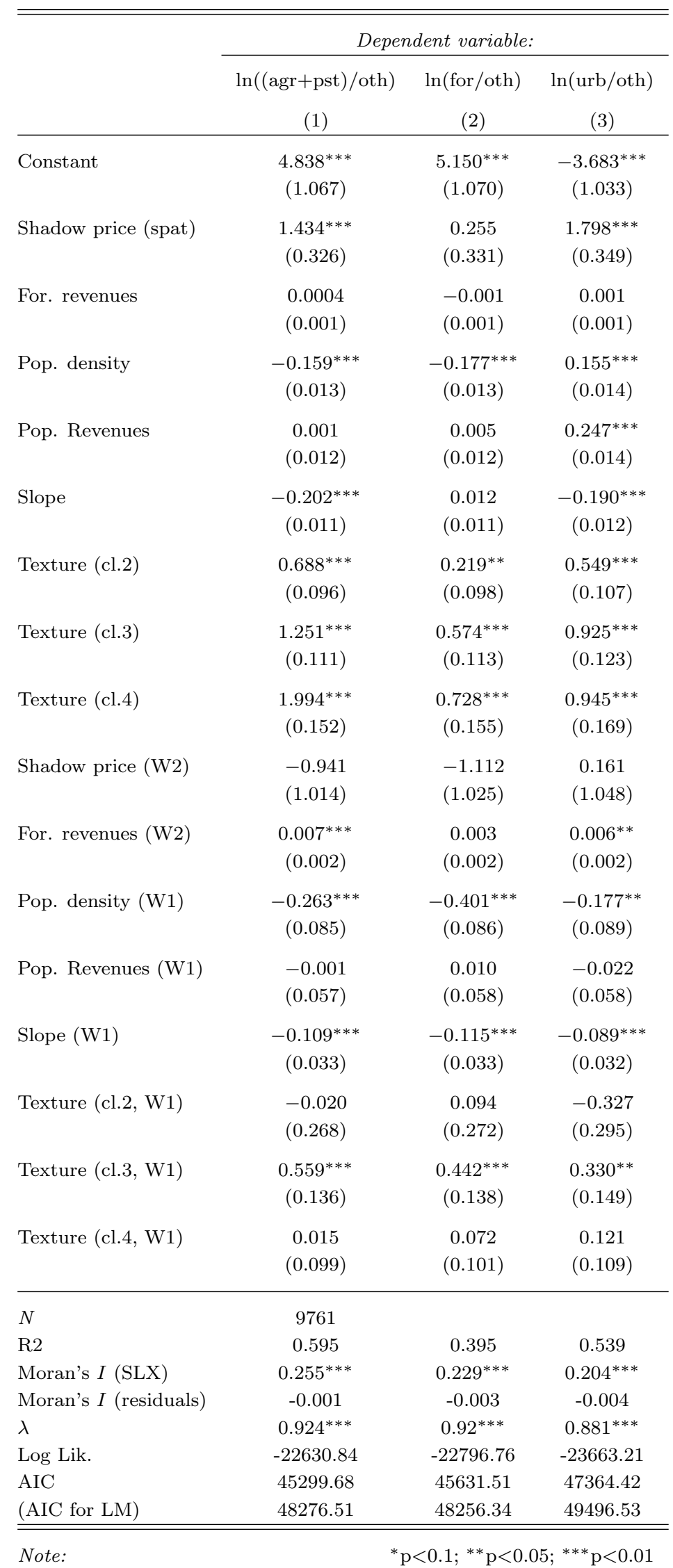

Table 9: Spatialized dual value, $4 \mathrm{LU}, 3^{\text {rd }}$ order $W_{1}, 1^{\text {st }}$ order $W_{2}$ 


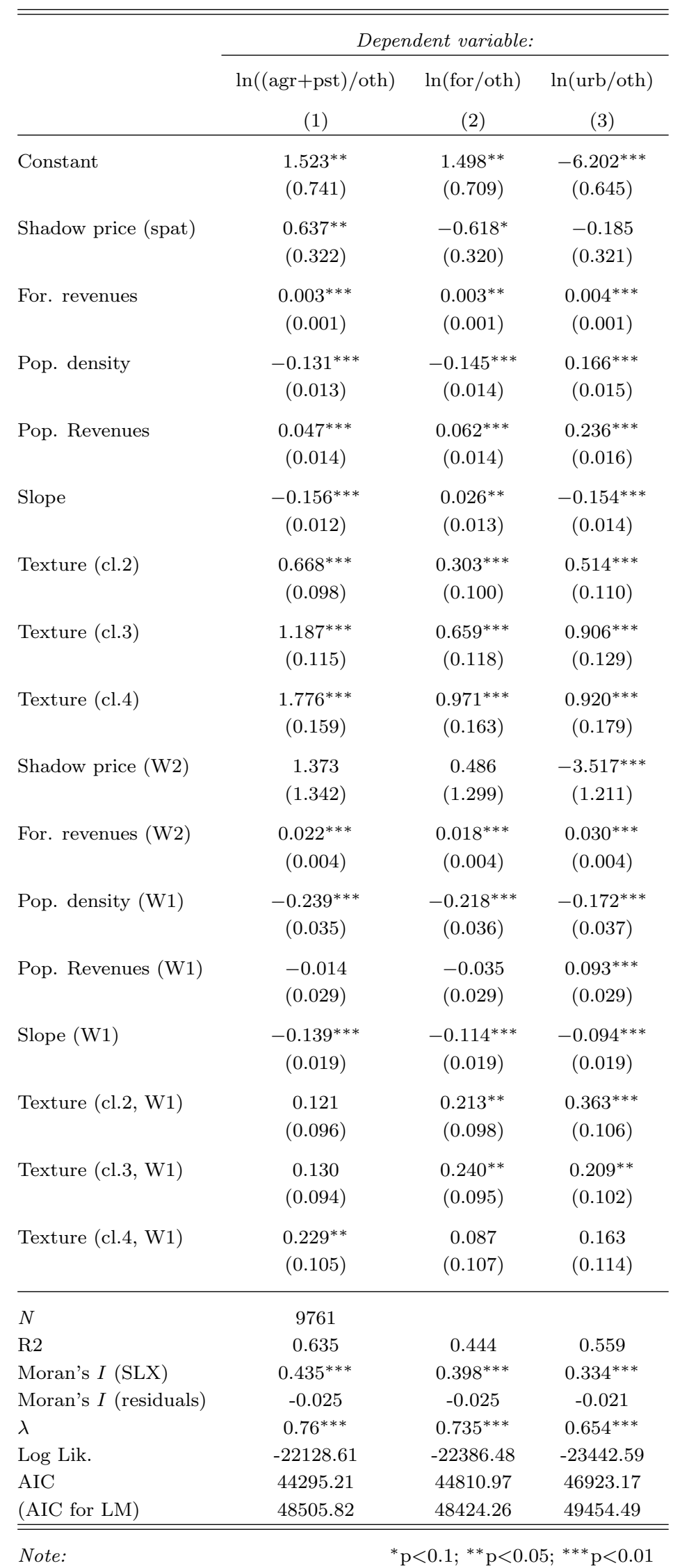

Table 10: Spatialized dual value, $4 \mathrm{LU}, 1^{\text {st }}$ order $W_{1}, 2^{\text {nd }}$ order $W_{2}$ 


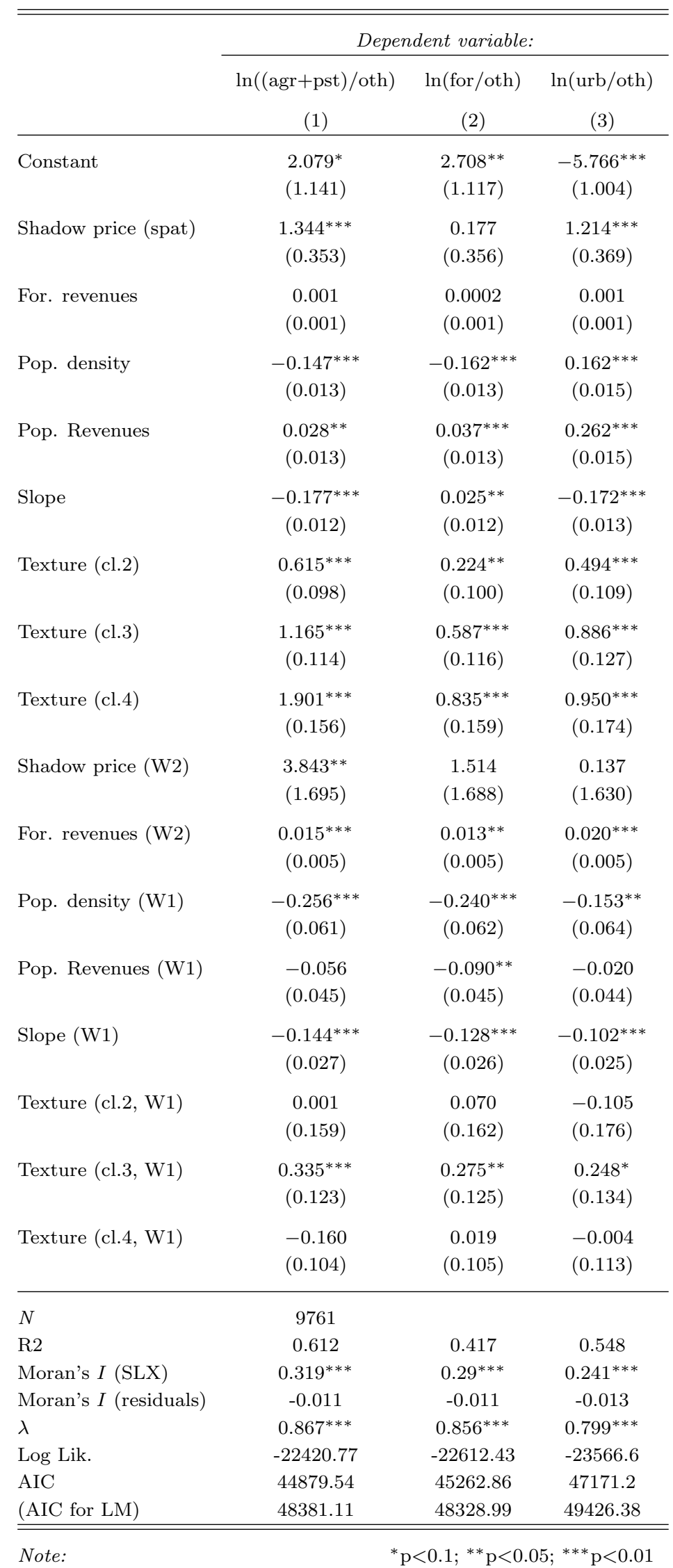

Table 11: Spatialized dual value, $4 \mathrm{LU}, 2^{\text {nd }}$ order $W_{1}, 2^{\text {nd }}$ order $W_{2}$ 


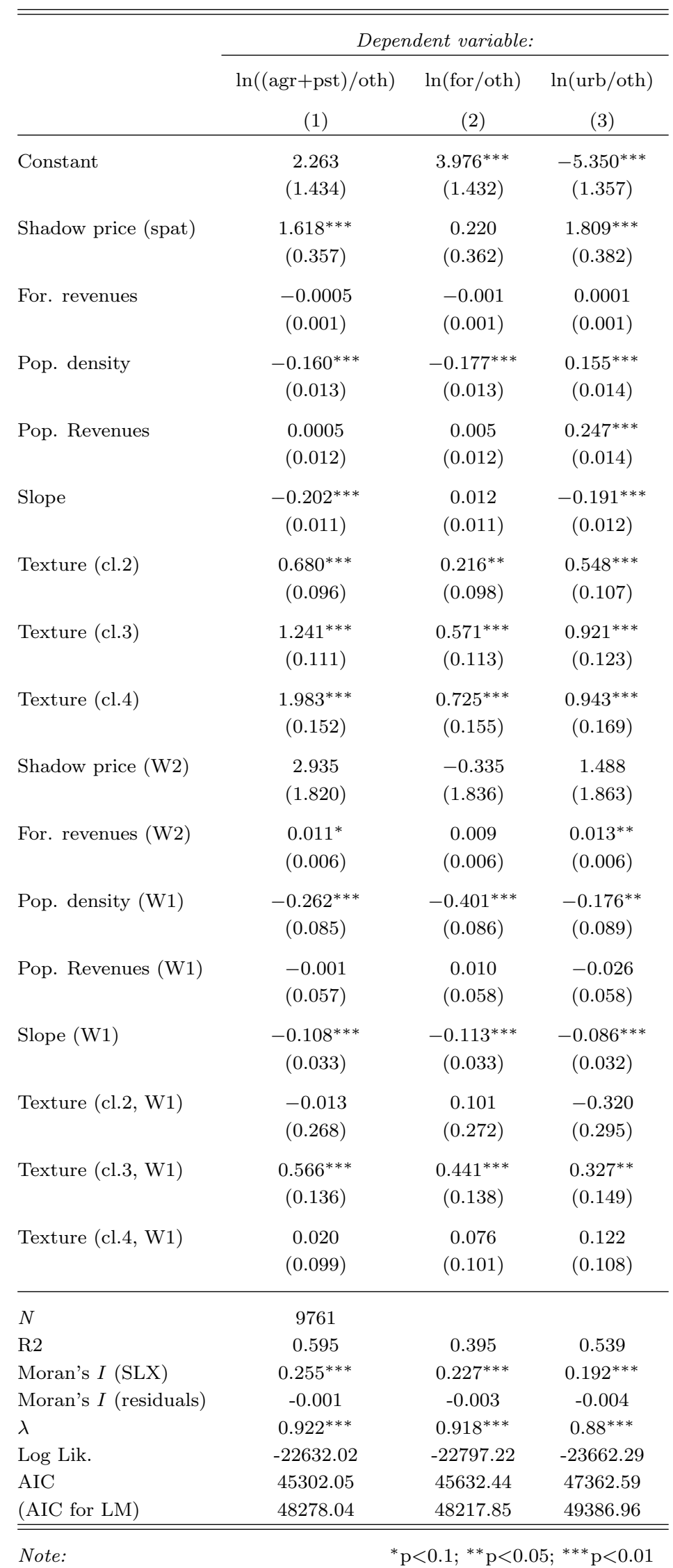

Table 12: Spatialized dual value, $4 \mathrm{LU}, 3^{\text {rd }}$ order $W_{1}, 2^{\text {nd }}$ order $W_{2}$ 